MAYRA CHRISTINA CAMPOS LIMA

\title{
Prevalência de alterações neurocognitivas associadas ao HIV em uma coorte aderente ao antirretroviral em um hospital geral na cidade de São Paulo
}

\author{
Dissertação apresentada à Faculdade de Medicina da \\ Universidade de São Paulo para a obtenção do título de \\ Mestre em Ciências \\ Programa de Dermatologia \\ Orientador: Prof. Dr. Jorge Simão do Rosário Casseb
}

(Versão corrigida. Resolução CoPGr 6018/11, de 1 de novembro de 2011. A versão original está disponível na Biblioteca da FMUSP) 


\section{Dados Internacionais de Catalogação na Publicação (CIP)}

Preparada pela Biblioteca da

Faculdade de Medicina da Universidade de São Paulo

Creprodução autorizada pelo autor

Lima, Mayra Christina Campos

Prevalência de alterações neurocognitivas associadas ao HIV em uma coorte aderente ao antirretroviral em um hospital geral na cidade de São Paulo / Mayra Christina Campos Lima. -- São Paulo, 2017.

Dissertação(mestrado)--Faculdade de Medicina da Universidade de São Paulo.

Programa de Dermatologia.

Orientador: Jorge Simão do Rosário Casseb.

Descritores: 1.HIV 2.Transtornos neurocognitivos 3.Terapêutica 4.Psicologia 5.População 6.Brasil 7.Adesão à medicação

USP/FM/DBD-361/17 


\section{DEDICATÓRIA}

A todos os pacientes do ambulatório ADEE 3002 que, ao longo de todo o processo de construção e execução deste projeto, me proporcionaram a oportunidade de aprendizado, evolução pessoal e profissional, me permitindo adentrar em suas histórias, sofrimentos e alegrias.

Agradeço por confiar em meu trabalho como psicóloga, pois este vai ao encontro do sentimento de utilidade de minha existência.

Aos pacientes, minha eterna gratidão. 


\section{AGRADECIMENTOS}

Ao meu marido Gustavo, engenheiro dedicado, inteligente ao extremo e a mente mais inquieta que eu já conheci. Obrigada por todo amor, companheirismo e incentivo.

Aos meus pais José Maria e Cecilia, que sempre me ensinaram a valorizar o conhecimento e estudo. Obrigada por sempre torcerem por mim durante o meu caminhar.

Ao meu orientador Prof. Dr. Jorge S. do Rosário Casseb, por todo apoio, dedicação, compreensão e empenho durante a realização desta pesquisa.

A Dra. Maria Rita Polo Gascón, amiga excepcional e fundamental em minha vida. Obrigada por acreditar no meu trabalho desde o primeiro momento. Obrigada por compartilhar o seu tempo e seu conhecimento comigo, pela sua paciência em me ensinar e por sua compreensão. Você é parte fundamental desta pesquisa; sem você, nada teria acontecido.

A minha psicóloga Marlene, por todo o acolhimento e suporte emocional, que me possibilitaram o autoconhecimento e enfrentamento das dificuldades.

Ao programa de Pós-Graduação da Dermatologia da FMUSP pelos ensinamentos e suporte financeiro a esta pesquisa.

Aos meus amigos do Ambulatório ADEE 3002 que sempre me recebiam às terçasfeiras com carinho e disposição, proporcionando um ambiente de aprendizado e de alegria.

Aos funcionários da pós-graduação do Departamento da Dermatologia, Ruth e Marcelo, que sempre me trataram com respeito, atenção, compreensão e paciência diante das minhas dúvidas, com certeza vocês ajudaram este trabalho a se tornar real.

Aos meus amigos, todos eles, por estarem ao meu lado em momentos importantes, fazendo tudo ter sentido. Obrigada. 
Esta dissertação está de acordo com as seguintes normas, em vigor no momento desta publicação:

Referências: adaptado de International Committee of Medical Journals Editors (Vancouver).

Universidade de São Paulo. Faculdade de Medicina. Divisão de Biblioteca e Documentação. Guia de apresentação de dissertações, teses e monografias. Elaborado por Anneliese Carneiro da Cunha, Maria Julia de A. L. Freddi, Maria F. Crestana, Marinalva de Souza Aragão, Suely Campos Cardoso, Valéria Vilhena. 3a ed. São Paulo: Divisão de Biblioteca e Documentação; 2011.

Abreviaturas dos títulos dos periódicos de acordo com List of Journals Indexed in Index Medicus. 


\section{Sumário}

Lista de Siglas e Abreviações

Lista de Tabelas

Lista de Figuras

Resumo

Abstract

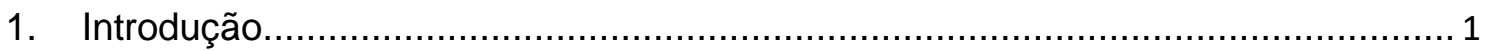

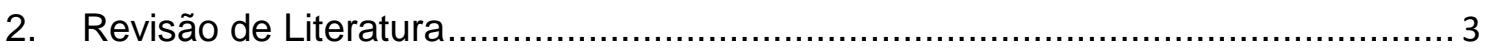
a. HIV e Sistema Nervoso Central ................................................................... 3
b. HIV e Alterações Neurocognitivas ......................................................... 3

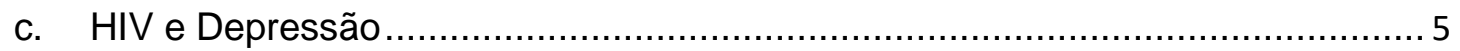

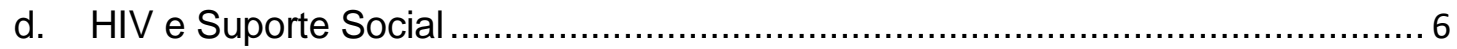

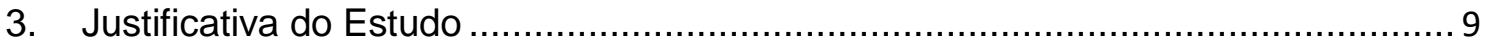

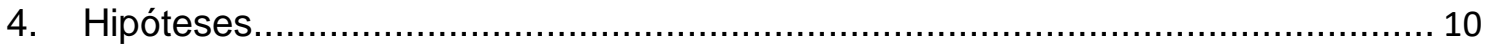

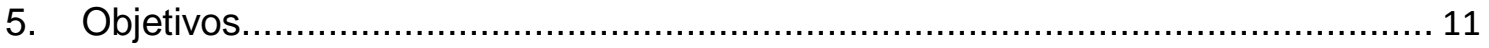

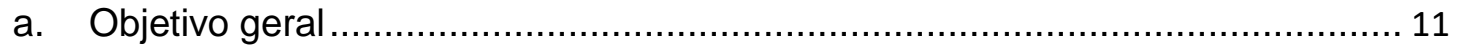

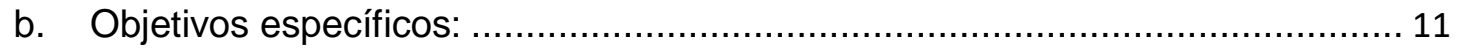

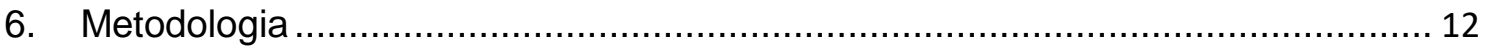

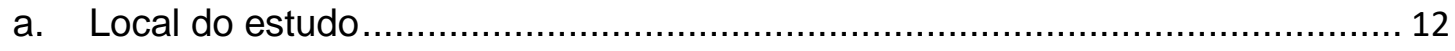

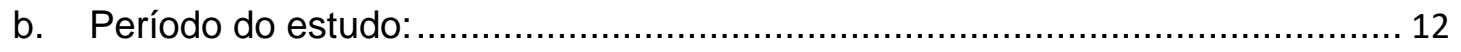

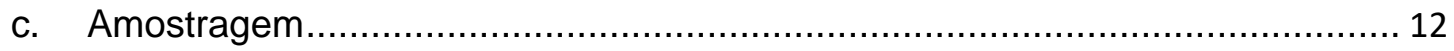

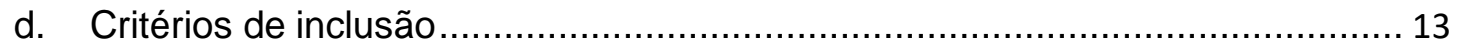

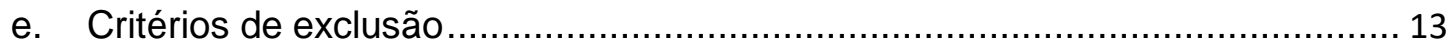

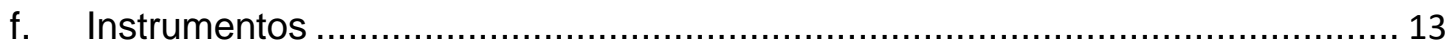

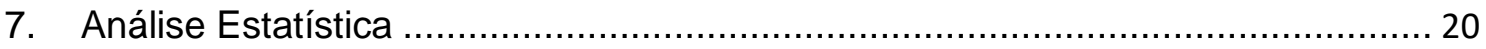

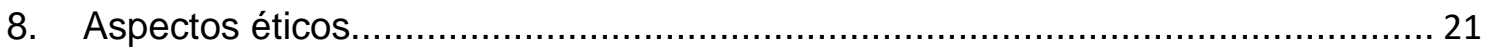

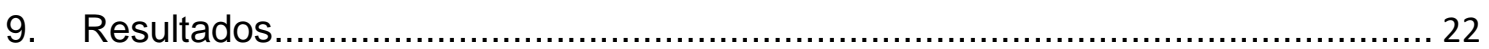

a. Perfil Sociodemográfico e clínico.................................................................. 22

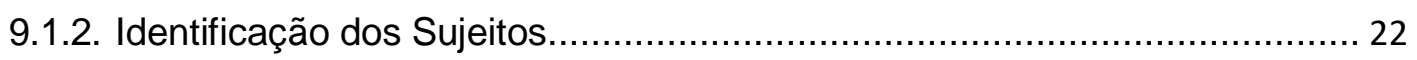

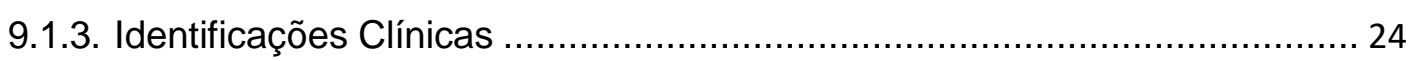

9.2 Avaliação do Estado de Humor, Suporte Social e Adesão a HAART ............ 26

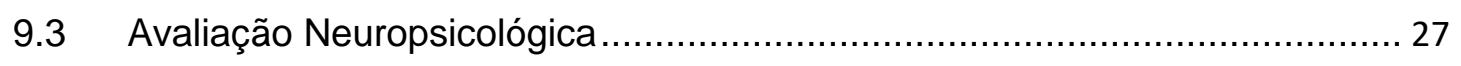

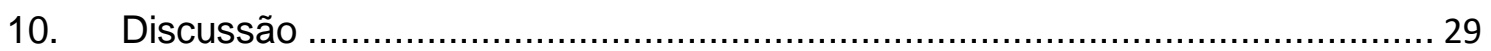

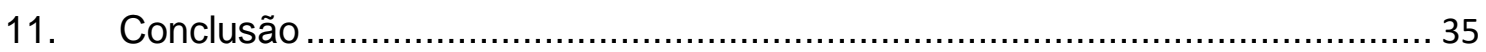




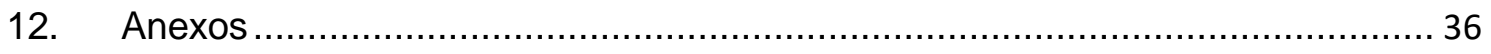

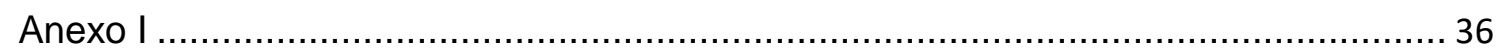

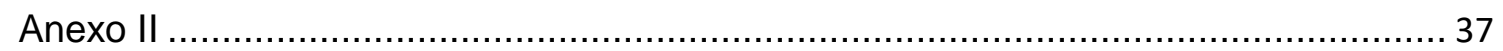

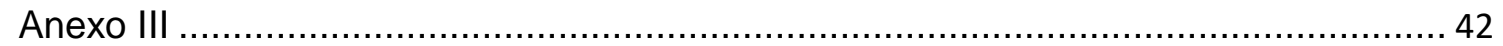

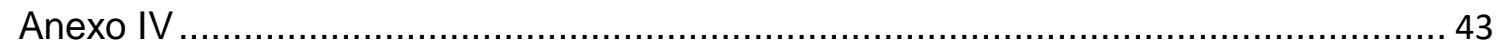

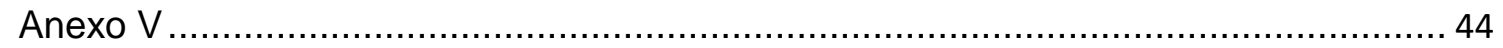

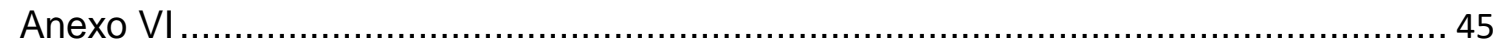

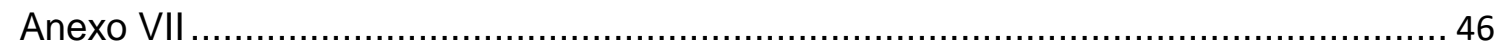

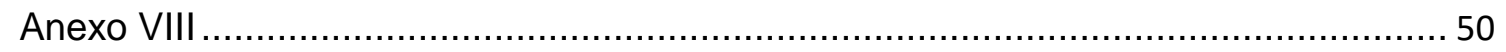

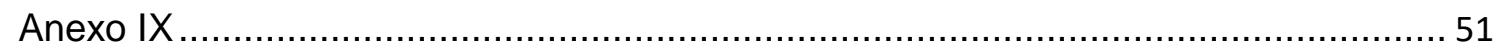

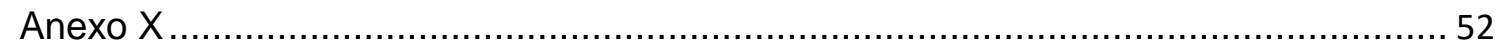

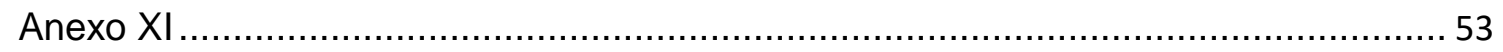

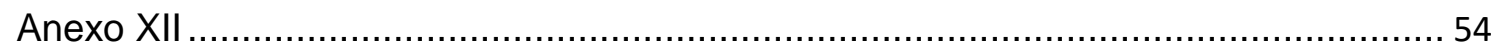

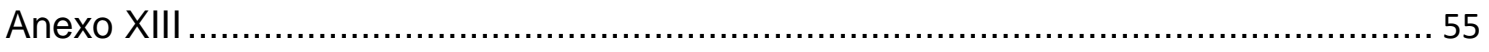

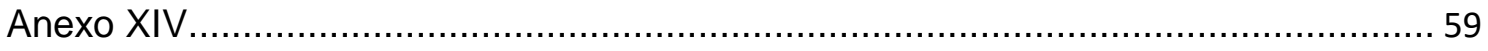

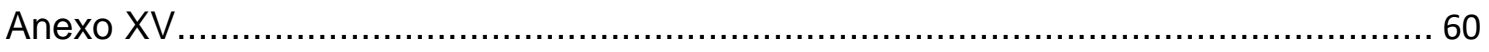

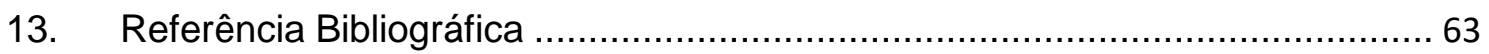




\section{Lista de Siglas e Abreviações}

AIDS: Acquired Immune Deficiency Syndrome ANCOVA: Analysis of Covariance

ANI: Asymptomatic Neurocognitive Impairment

ANOVA: Analysis of Variance

ASSIST: Alcohol, Smoking and Substance Involvement Screening Test

BHE: Barreira Hemato-Encefálica

CD4: Cluster of Differentation 4

CEAT: Cuestionario para la Evaluación de la Adhesión al Tratamiento Antiretroviral

CPE: CNS Penetration-Effectiveness

HAART: Highly Active Antiretroviral Therapy

HAD: HIV Associated Dementia

HADS: Hospital Anxiety and Depression Scale

HAND: HIV Associated Neurocognitive Disorders

HBV: Hepatitis B Virus

HCFMUSP: Hospital das Clínicas da Faculdade de Medicina da Universidade de São

Paulo

HCV: Hepatitis C Virus

HDL: High-Density Lipoprotein Cholesterol

HIV: Human Immunodeficiency Virus

HTLV: Vírus Linfotrópico da Célula T Humana

IHDS: International HIV Dementia Scale

LCR: Líquido Cefalorraquidiano

LDL: Low-Density Lipoprotein Cholesterol

MND: Mild Neurocognitive Disorder

OMS: Organização Mundial de Saúde

PVHA: Pessoas Vivendo com HIVIAids

RAVLT: The Rey Auditory-Verbal Learning Test

RNA: Ribonucleic Acid

SNC: Sistema Nervoso Central

TARV: Terapia Altamente Eficaz com Antirretrovirais

TCLE: Termo de Consentimento Livre e Esclarecido

WAIS III: Escala de Inteligência para Adultos 


\section{Lista de Tabelas}

Tabela 1: Características Demográficas e Clínicas .................................................... 23

Tabela 2: Escala de Atividade de Vida Diária de Lawton .........................................24

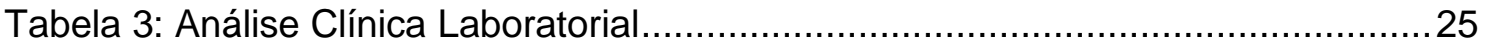

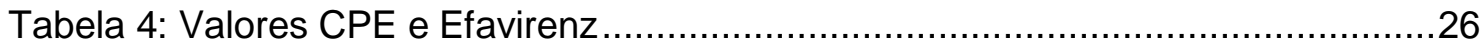

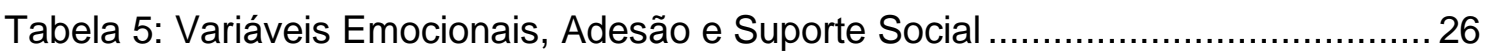

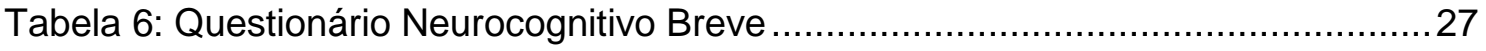

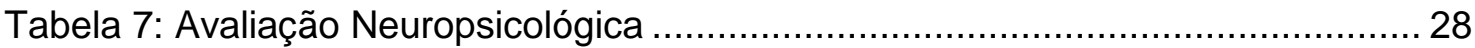




\section{Lista de Figuras}

Figura 1: Fluxograma dos pacientes entrevistados e incluídos na amostra.................22 


\section{Resumo}

Lima MCC. Prevalência de alterações neurocognitivas associadas ao HIV em uma coorte aderente ao antirretroviral em um hospital geral na cidade de São Paulo [Dissertação]. São Paulo: Faculdade de Medicina, Universidade de São Paulo; 2017

Objetivos: Este trabalho teve como objetivo determinar a prevalência e os fatores associados às alterações neurocognitivas em uma coorte de pacientes portadores do HIV-1 vinda do Banco de Sangue do Hospital das Clínicas da Faculdade de Medicina da Universidade de São Paulo HC-FMUSP, com alto nível de adesão aos antirretrovirais e baixa prevalência de doenças oportunistas associadas ao vírus. Metodologia: A prevalência de alterações neurocognitivas associadas ao HIV (HAND) foi avaliada através de uma bateria neuropsicológica estruturada composta por 8 instrumentos, possibilitando uma abrangência maior em relação a quantidade de funções cognitivas superiores avaliadas e maior precisão na detecção das alterações. Resultados: A amostra foi composta por 54 pacientes e a análise dos dados mostrou elevada prevalência de HAND na amostra analisada (60\%), independente do controle imunológico e virológico, com maior presença da forma assintomática (ANI), porém o resultado da forma leve (MND) também foi significativo, sendo próximo à porcentagem dos pacientes com a forma assintomática. Conclusão: Os resultados do estudo refletiram o cenário nacional e internacional mostrando a alta prevalência das alterações cognitivas associadas ao HIV, alertando os profissionais de saúde para a importância de identificação, diagnóstico e acompanhamento adequado desses pacientes. Os dados também mostraram a importância da presença do profissional da área de psicologia na equipe de saúde, oferecendo ao paciente o desenvolvimento de estratégias de atendimento mais específicas e eficazes.

Descritores: HIV; transtornos neurocognitivos; terapêutica; psicologia; população;

Brasil; adesão à medicação 


\begin{abstract}
Lima MCC. Prevalence of HIV neurocognitive disorders in an antiretroviral-adherence cohort at a general hospital in São Paulo [Dissertation]. São Paulo: "Faculdade de Medicina, Universidade de São Paulo"; 2017
\end{abstract}

The main goal of this study was to determine the prevalence and factors associated with neurocognitive disorders in a cohort of 54 patients with HIV-1 from the Blood Bank of the Hospital das Clínicas da Faculdade de Medicina da Universidade de São Paulo HCFMUSP with high adherence to antiretroviral therapy and low prevalence of opportunistic diseases associated with the virus.

Methods: The prevalence of HIV associated neurocognitive disorders (HAND) was evaluated through a structured neuropsychological battery of 8 tests, increasing the coverage of superior cognitive functions being evaluated and greater precision in the detection of cognitive alterations. Results: Data analysis showed a high prevalence of HAND in the population under analysis (60\%), irrespective of the immunological and virologic control, with a greater presence of the asymptomatic form (ANI), but the occurrence of the mild form (MND) was also significant, being close to the percentage of patients with the asymptomatic form. Conclusion: The result of the study reflected the national and international scenario showing high prevalence of HIV associated neurocognitive disorders, alerting health professionals to the importance of identification, diagnosis and adequate follow-up of these patients. The data also showed the importance of the presence of the psychologist in the health team, offering to the patient more specific and effective care strategies.

Descriptors: HIV; neurocognitive disorder; therapeutics; psychology; population;

Brazil; medication adherence 


\section{Introdução}

A infecção causada pelo vírus da imunodeficiência humana tipo 1 (HIV-1) continua a ser um problema de saúde pública de importância internacional(1). De acordo com dados da Organização Mundial de Saúde (OMS), havia aproximadamente 36,7 milhões de pessoas no mundo vivendo com o HIV no final de 2015, e grande parte desta população pode vir a apresentar comprometimento cognitivo, mesmo em indivíduos que estão fazendo o uso regular da terapia antirretroviral combinada altamente ativa $(\text { HAART) })^{(2-7)}$.

De acordo com o relatório do Unaids Brasil lançado em julho de 2016, a estimativa sobre HIV e Aids para o Brasil no ano de 2015 era de 610 mil a um milhão de indivíduos convivendo com o vírus, sendo que novas infecções atingiram de 31 mil a 57 mil indivíduos, chegando a 11 mil - 21 mil mortes relacionadas à Aids ${ }^{(8)}$.

Ainda em relação a população brasileira, a maior concentração da infecção está nos indivíduos com idade entre 25 e 39 anos para ambos os sexos, com destaque para o aumento entre os jovens de 15 a 24 anos $^{(8)}$. Isto mostra que as possíveis complicações do HIV, inclusive as alterações cognitivas, atingem diretamente a parcela da população economicamente ativa ${ }^{(6,8)}$, pois tendem a provocar alterações nas esferas cognitiva, comportamental e motora ${ }^{(3,4,9)}$.

As alterações cognitivas foram reconhecidas logo no início da epidemia na década de 1980 e caracterizadas clinicamente e neuropatologicamente por Price e Navia em $1986^{(10)}$. Estima-se que $15 \%$ a $50 \%$ das pessoas com o vírus apresentam

algum nível de alteração cognitiva associada ao HIV, essa variação depende da população alvo e dos métodos usados para avaliar o comprometimento cognitivo ${ }^{(3,6,7)}$.

O termo HIV Associated Neurocognitive Disorders (HAND) é uma denominação genérica que engloba as três categorias de comprometimento cognitivo: assintomático (ANI - Asymptomatic Neurocognitive Impairment) e alteração cognitiva leve/moderada

(MND - HIV Associated Mild Neurocognitive Disorder) que correspondem às formas leves e intermediárias; e, por fim, demência associada ao HIV (HAD - HIV Associated Dementia), sendo classificada como a forma mais grave ${ }^{(11,12)}$.

A introdução da HAART possibilitou um maior controle efetivo da replicação viral e melhora do estado imunológico dos pacientes, ocasionando também a diminuição dos casos de $\operatorname{HAD}^{(4,7,9,11)}$. Entretanto, devido ao fato do SNC ser um santuário imunológico, o diagnóstico das formas leves e intermediárias de HAND ainda é muito frequente, mesmo diante dos avanços farmacológicos ${ }^{(2-7)}$. 
Muitos estudos têm sido feitos em diferentes coortes com o intuito de ampliar a compreensão sobre a prevalência de HAND diante dos mais avançados antirretrovirais. Um estudo brasileiro apontou que 53,2\% de um total de 114 pacientes apresentaram comprometimento neuropsicológico ${ }^{(4)}$. Uma coorte americana mostrou que os indivíduos HIV+ apresentaram comprometimento nos domínios atenção auditiva, aprendizagem verbal e memória ${ }^{(6)}$. Os resultados de uma coorte da Etiópia mostraram que os riscos de alterações neurocognitivas associada ao HIV foi de $36,4 \%{ }^{(13)}$. É importante que a avaliação das funções cognitivas seja integrada aos demais exames rotineiros, pois as alterações podem interferir na qualidade de vida do paciente, prejudicar suas funções laborativas e incidir negativamente na adesão ao tratamento ${ }^{(13-16)}$.

Com isso, nosso estudo buscou encontrar a prevalência das alterações neurocognitivas em indivíduos HIV+ de uma coorte de pacientes oriundos do Banco de Sangue do Hospital das Clínicas-SP, com alto nível de adesão aos antirretrovirais e praticamente sem histórico de doenças oportunistas associadas ao HIV, a fim de encontrar uma melhor compreensão sobre o assunto em nossa realidade e contribuir para atuações futuras, bem como verificar se as variáveis depressão e suporte social estariam interferindo no comprometimento cognitivo. 


\section{Revisão de Literatura}

\section{a. HIV e Sistema Nervoso Central}

O HIV entra no cérebro precocemente através da migração de células mielóides e linfóides e estabelece infecção em macrófagos perivasculares e micróglia, sendo que algumas infecções também ocorrem nos astrócitos ${ }^{(3,17)}$, que atravessam a barreira hemato-encefálica (BHE) pelo mecanismo "Cavalo de Tróia". No cérebro, o vírus infecta as células gliais que em última instância secretam neurotoxinas que levam ao dano e possível morte neuronal(17).

O HIV pode permanecer latente no SNC por muitos anos e sua presença pode levar a déficits sutis no funcionamento cognitivo, independente da supressão de HIVRNA no sangue ${ }^{(18)}$. Esta independência da presença do vírus entre o plasma sanguíneo e o SNC pode ser resultado da má distribuição dos antirretrovirais no SNC. A distribuição dos medicamentos antirretrovirais e a toxicidade no SNC podem afetar a tomada de decisão clínica, apesar de este tópico ser ainda bastante debatido ${ }^{(3,7,11)}$.

De acordo com Letendre, 2011, a eficácia dos antirretrovirais está relacionada com o escore da efetividade de penetração no SNC (CPE, Índice de PenetraçãoEficácia), esse mecanismo atribui um valor numérico para cada antirretroviral de acordo com as propriedades químicas. Dessa forma, escores mais elevados estariam associados a uma melhor penetração do fármaco no SNC, tendo como orientação clínica propor esquemas terapêuticos com CPE $\geq 8^{(19)}$.

Há autores que defendem que uma maior pontuação de CPE estaria associada com maior chance de carga viral indetectável no SNC, bem como melhora no funcionamento cognitivo. Entretanto, há diversas discordâncias sobre o assunto, havendo a necessidade de mais estudos específicos ${ }^{(11)}$.

\section{b. HIV e Alterações Neurocognitivas}

A presença do HIV no SNC pode gerar sintomas que incluem a lentificação na velocidade do processamento mental, alteração na memória, diminuição da capacidade de concentração, apatia, perda de interesse no trabalho e nas atividades de lazer; com o passar do tempo, esses prejuízos tornam-se mais graves interferindo na realização das tarefas da vida diária, e geralmente são acompanhados de $\operatorname{sintomas~psiquiátricos~}^{(6,}$ 20). 
A atual classificação das alterações neurocognitivas segue os critérios da Academia Americana de Neurologia, também conhecido como Critérios de Frascati ${ }^{(21)}$. Os indivíduos são classificados de acordo com o aumento da severidade das alterações cognitivas, sem haver a possibilidade de correlação com comorbidades:

- Alteração Neurocognitiva Assintomática (ANI, asymptomatic neurocognitive impairment): há alterações de $\geq 2$ domínios cognitivos, em pelo menos um desvio padrão abaixo da média na avaliação e sem impacto nas atividades de vida diária;

- Comprometimento Neurocognitivo Leve/moderado (MND, mild neurocognitive disorder): há alterações de $\geq 2$ domínios cognitivos em pelo menos um desvio padrão abaixo da média na avaliação neuropsicológica e com comprometimento leve nas atividades de vida diária;

- Demência Associada ao HIV (HAD, HIV- associated dementia): há alterações graves de $\geq 2$ domínios cognitivos, geralmente o distúrbio é encontrado em múltiplos domínios, especialmente no aprendizado de novas informações, lentificação no processamento de novas informações e déficit em atenção e concentração e com comprometimento significativo nas atividades de vida diária.

Com a introdução da terapia antirretroviral de alta potência (HAART), a Aids passou a ter status de doença crônica, pois a probabilidade de adoecimento e morte diminuiu diante de um adequado tratamento. Embora uma boa adesão ao antirretroviral possa proporcionar a supressão viral plasmática, as taxas de declínio neurocognitivo estão aumentando, principalmente quanto às formas mais leves e moderadas (ANI e MND) $)^{(2-7,9,11,22) . ~}$

Avaliar clinicamente o declínio na função cognitiva pode ser importante uma vez que sugere um processo ativo, potencialmente reversível que requer uma investigação mais aprofundada e talvez mudanças na gestão(23).

O perfil das manifestações neurocognitivas mudou drasticamente após a era HAART, caracterizando-se por uma incidência reduzida de HAD e aumento de MND e $\operatorname{ANI}{ }^{(5,22)}$. Atualmente, estimam-se prevalências de $15-30 \%$ para ANI, 20-50\% para MND e 2-8\% para $\mathrm{HAD}^{(5,22,24,25)}$. Esses dados são constantes independentemente do local estudado, indo ao encontro com alguns pesquisadores que sugerem que a metade dos pacientes infectados com HIV na Europa e nos EUA podem ter algum comprometimento cognitivo, com predominância da forma assintomática(3).

Existem muitos fatores que podem contribuir para um prognóstico de prejuízos neurocognitivos em pacientes infectados pelo HIV. Comorbidades, como por exemplo, a infecção pela hepatite $C$ está amplamente associada com disfunção cognitiva ${ }^{(26)}$, nadir de CD4<200 células $/ \mathrm{mm}^{3}{ }^{(2)}$, uso de drogas psicoativas ${ }^{(27)}$, fatores de risco 
cardiovascular $^{(21)}$, diabetes ${ }^{(21)}$, nível de escolaridade baixo ${ }^{(28)}$ e transtornos de ansiedade e depressão, sendo que estes podem mascarar o comprometimento cognitivo ${ }^{(4,29)}$. Deste modo, Nightingale et al (2014) indicam que várias condições devem ser consideradas na avaliação de pacientes com infecção pelo HIV e comprometimento cognitivo, e uma avaliação clínica cuidadosa é essencial(3).

Com relação ao nosso país, ainda existem poucos trabalhos sobre a prevalência de HAND realizados no Brasil, a maioria das publicações é oriunda de países com características diferentes das nossas, principalmente no que se refere ao nível de educação e renda ${ }^{(4,30)}$. Porém, estudos feitos em diferentes regiões mostram que a prevalência varia entre $4,6 \%$ a $52,4 \%(4,31,32)$.

Rocha et al. (2011) estudaram 18 pacientes com HIV/aids atendidos no Hospital Regional de Assis (Assis-SP) e constataram algum tipo de prejuízo cognitivo em 34\% dos participantes ${ }^{(31)}$. Em um estudo no Rio de Janeiro foram avaliados 20 indivíduos e apenas um apresentou desempenho das funções cognitivas muito abaixo da média(33). Oliveira et al. (2006) atribuíram o diagnóstico de demência associada ao HIV a 4,6\% dos 194 pacientes com doenças neurológicas de um hospital de Belo Horizonte ${ }^{(34)}$. Um estudo com 52 pacientes com mais de 50 anos em dois hospitais do Recife encontrou a presença de HAND em 36,5\%(32). Por fim, um estudo, em Marília - SP, que avaliou 111 pacientes com a International HIV Dementia Scale (IHDS) obteve um diagnóstico potencial de HAND em $53,2 \%$ dos participantes ${ }^{(35)}$.

Deste modo, existe a necessidade na ampliação de estudos sobre este tema em nossa população, pois conhecer a nossa realidade quanto à prevalência de HAND, os possíveis fatores associados e testar instrumentos de diagnóstico, tem grande importância para uma melhor eficácia na relação equipe de saúde e paciente ${ }^{(4)}$.

\section{c. HIV e Depressão}

A depressão é o transtorno psiquiátrico mais prevalente dentre todos os que são identificados nos indivíduos HIV+, tendo estimativas de prevalência de $20 \%$ a 37\%, ou seja, uma ocorrência 3 vezes maior que na população geral(29,36,37). Os sintomas depressivos estão associados com sentimentos de inutilidade, desesperança, perda de interesse, problemas de concentração e pensamentos pessimistas, que provavelmente atuam como empecilhos para com o autocuidado necessário diante do tratamento ${ }^{(4,29)}$.

Um estudo com 114 participantes HIV+ realizado na cidade de Marília - SP, apresentou a prevalência de transtornos depressivos em $26,3 \%$ dos pacientes ${ }^{(4)}$. Entretanto, em outro estudo feito na cidade de São Paulo, que teve como objetivo avaliar 
ao longo de 1 ano a aderência ao tratamento em 268 adolescentes infectados com HIV, mostrou que a presença de sintomas de estresse e depressão não foram preditores significativos na adesão; no entanto, uma análise adicional revelou que os jovens que permaneceram não aderentes durante o período da pesquisa estavam mais deprimidos do que aqueles que permaneceram aderentes ${ }^{(38)}$.

A maior presença de depressão em pessoas vivendo com HIVIAids (PVHA) tem a ver com o fato do HIV ser uma doença crônica e estigmatizante, e por isso exige a adequação de uma nova rotina ${ }^{(29)}$. O impacto social negativo da doença influencia no bem-estar psicossocial das PVHA e um adequado suporte social age como fator de proteção diante de possíveis complicações emocionais ${ }^{(39,40)}$. Além disso, as sequelas da infecção, as doenças oportunistas e os efeitos colaterais do tratamento tendem a imitar os sintomas de depressão como fadiga, somatização, perda de peso, falta de apetite, alteração da concentração, entre outros ${ }^{(4,41)}$.

Para Blazer (2003), a depressão está associada a déficits cognitivos e funcionais, mesmo em pacientes com sintomas depressivos menos graves ${ }^{(42)}$. Estudos sugerem a presença de déficits neuropsicológicos em episódio depressivo maior ${ }^{(43)}$. As funções cognitivas mais comumente afetadas são: evocação após intervalo de tempo, aquisição da memória, atenção, concentração, flexibilidade cognitiva e abstração(44).

De acordo com Alexoupolos et. al. (2002); Pálsson, Johansson, Berg e Skoog (2000); Portella e Marcos (2002), o impacto da depressão foi observado em diferentes áreas cognitivas, com prejuízos nas seguintes funções: funções executivas, memória, velocidade de processamento das informações, habilidades viso-espaciais e flexibilidade mental. A maioria dos estudos aponta a hipótese que quanto mais grave a depressão, maiores serão os déficits cognitivos (Alexoupolos, 2005)(45,46).

A alta prevalência de sintomas de depressão nas PVHA indica a necessidade de avaliação diagnóstica continua, e a identificação das variáveis associadas permitirá que a equipe de saúde desenvolva novas estratégias de intervenção que alcance melhor os pacientes $^{(29,40)}$.

\section{d. HIV e Suporte Social}

A introdução da HAART facilitou o controle e tratamento da infecção pelo HIV; porém, o estigma e a discriminação ainda são presentes neste diagnóstico. Os pacientes muitas vezes vivenciam o isolamento social e dificuldades no campo afetivo sexual, gerando prejuízos na manutenção e estruturação da sua rede de suporte social $(39,47)$. 
O suporte social pode ser entendido como qualquer processo em que relações sociais promovem saúde e bem-estar influenciando, diretamente, na qualidade de vida do indivíduo ${ }^{(39,48,49)}$. Quando disponibilizado de forma adequada, o suporte social atua diretamente na prevenção de doenças, na promoção da saúde, na adesão terapêutica e no processo de recuperação da doença ${ }^{(48-50)}$.

Há duas categorias de suporte social: o primeiro, chamado de suporte emocional inclui as atividades voltadas à atenção, companhia e escuta, contribuindo para que a pessoa se sinta cuidada ou valorizada. Já o suporte instrumental se refere ao auxílio em tarefas domésticas ou em aspectos práticos do próprio tratamento, como acompanhar a pessoa em um atendimento, buscar os medicamentos na unidade de saúde, tomar conta dos filhos nos dias de consulta, dentre outras atividades ${ }^{(39,47-50)}$.

Em um estudo realizado com 179 pacientes HIV+ de um hospital universitário em Santa Maria, interior do estado do Rio Grande do Sul, 57\% dos pacientes referiram sempre ter apoio que o fizessem sentir valorizados, 49,7\% sentiam-se apoiados com relação ao estado de humor e 46,9\% recebiam ajuda nas atividades diárias do tratamento, tendo esse resultado impactado positivamente na reestruturação de uma nova rotina atrelada ao diagnóstico ${ }^{(50)}$. Em um recente estudo qualitativo com 23 mulheres afro-americanas, mais da metade das participantes relataram a necessidade de aumento do apoio social, especialmente o apoio da equipe de saúde, familiares e colegas soropositivos $^{(47)}$. Já outro estudo brasileiro que avaliou a qualidade de vida de 625 participantes, mostrou que um adequado suporte social atua diretamente na redução de sintomas de ansiedade diante da possibilidade do paciente poder compartilhar o seu status de HIV com alguém ${ }^{(51)}$.

As habilidades sociais e de execução das tarefas da vida diária é um complemento importante na avaliação cognitiva. A alteração neurocognitiva é clinicamente significativa quando afeta a independência do paciente, sendo que os indivíduos infectados com alterações cognitivas leves podem apresentar problemas ocupacionais, mesmo nos estágios iniciais da doença ${ }^{(6,20,21)}$.

Indivíduos HIV positivos com alterações cognitivas, principalmente, em funções executivas e processos de aprendizagem apresentam, geralmente, menor desempenho no trabalho. Os déficits de atenção, memória de trabalho e abstração/função executiva são os domínios cognitivos mais diretamente relacionados às dificuldades do funcionamento das atividades diárias e sociais nas pessoas com infecção pelo $\mathrm{HIV}^{(2,6,45}$, 46, 52).

A adequada rede de suporte social possibilita ao paciente uma melhor adesão ao tratamento, uma redução do estresse, dos problemas mentais e ameniza o 
sofrimento diante das possíveis alterações cognitivas, além de proporcionar melhora da autoestima e do bem-estar psicológico. Sendo assim, é necessário avaliar a rede de apoio dos pacientes, bem como a relação com a equipe de saúde ${ }^{(39,48-50)}$. 


\section{Justificativa do Estudo}

A infecção causada pelo HIV-1 continua a ser um problema de saúde pública internacional, sendo que a estimativa para a população brasileira no ano de 2015 era de 610 mil a um milhão de indivíduos convivendo com o vírus(1, 8, 53). Até 2030, estimase que todos os portadores do vírus estarão em tratamento antirretroviral e que haverá uma redução de mais de 17 milhões de novas infecções ${ }^{(2)}$.

A boa adesão a HAART pode proporcionar a supressão viral plasmática; entretanto, as alterações cognitivas permanecem comuns aos pacientes aderentes, sem necessariamente terem tido doenças oportunistas ${ }^{(2-7,9,11,22)}$. Diante deste cenário, faz-se necessário o desenvolvimento de pesquisas que possam auxiliar na compreensão dos fatores envolvidos nas alterações cognitivas associadas ao HIV (HAND), e a realização da avaliação neuropsicológica é um instrumento útil para auxiliar no diagnóstico de HAND, permitindo ao infectologista, psiquiatra, psicólogo e neurologista obter informações que subsidiem o diagnóstico etiológico.

O exame neuropsicológico pode fornecer pistas importantes na distinção entre diagnóstico topográfico, a uma perda de habilidades (déficits cognitivos) e secundário a um quadro depressivo, associado ou não ao comprometimento cognitivo, fornecendo subsídios para a execução das medidas terapêuticas e de reabilitação a serem realizadas em cada caso. Assim, a avaliação neuropsicológica de uma amostra de pacientes em ambulatório especializado, cujas características desta coorte fizeram com que os dados obtidos tivessem menos interferência de outras variáveis na parte cognitiva, pôde trazer informações quanto à prevalência de HAND e verificou a possibilidade de que as variáveis depressão e suporte social estariam interferindo no comprometimento cognitivo. 


\section{Hipóteses}

1) Pacientes portadores do HIV-1 com alteração neurocognitiva apresentam maior presença de sintomas depressivos e de ansiedade, quando comparados aos pacientes portadores do vírus preservados cognitivamente;

2) Pacientes portadores do HIV-1 com alteração neurocognitiva apresentam prejuízos no suporte social, emocional e instrumental, quando comparados aos pacientes portadores do vírus sem o comprometimento cognitivo;

3) Pacientes portadores do HIV-1 com alteração neurocognitiva apresentam pior adesão ao tratamento antirretroviral, quando comparados aos pacientes portadores do vírus sem o prejuízo cognitivo. 


\section{Objetivos}

\section{a. Objetivo geral:}

Investigar a prevalência e os fatores associados às alterações neurocognitivas em uma coorte de pacientes portadores do HIV-1 vinda do Banco de Sangue do Hospital das Clínicas da Faculdade de Medicina da Universidade de São Paulo HC-FMUSP, com alto nível de adesão aos antirretrovirais e baixa prevalência de doenças oportunistas associadas ao vírus.

\section{b. Objetivos específicos:}

1) Comparar o desempenho cognitivo em pacientes infectados pelo HIV-1 nas três categorias de HAND: assintomática, leve/moderada e demência associada ao HIV (ANI, MDN e HAND) com os pacientes sem perda cognitiva;

2) Verificar a frequência dos sintomas de Depressão e Ansiedade e possível interferência nas funções cognitivas superiores;

3) Verificar se a falta do Suporte Social interfere na cognição, no humor e na adesão aos antirretrovirais;

4) Verificar se os pacientes com comprometimento cognitivo apresentam menor adesão ao antirretroviral. 


\section{Metodologia}

O estudo foi conduzido conforme desenho transversal, mediante a comparação dos desempenhos entre pacientes com sorologia positiva para HIV-1 com a presença de alterações neurocognitivas associadas ao vírus, e pacientes soropositivos sem o comprometimento cognitivo em testes neuropsicológicos. Também foram realizadas medidas de comparação intragrupo.

\section{a. Local do estudo}

Ambulatório de pacientes infectados pelo HIV-1, chamado ADEE 3002, do Hospital das Clínicas da Faculdade de Medicina da Universidade de São Paulo (HCFMUSP). O ambulatório ADEE 3002 tem aproximadamente 470 pacientes ativos, todos os pacientes foram encaminhados pelo Banco de Sangue do HC-FMUSP, ou seja, todos os pacientes eram doadores de sangue e num determinado momento souberam do seu status positivo para o HIV através da análise feita após a doação de sangue. Esta característica possibilita uma coorte de paciente mais homogênea com relação à baixa prevalência de doenças oportunistas associadas ao HIV; muitos dos pacientes se mantém apenas como portadores do vírus, não desenvolvendo o quadro de Aids; são assíduos às consultas médicas; apresentam alto índice de adesão ao antirretroviral e apresentam alta prevalência de carga viral indetectável. É importante também ressaltar que grande parte dos pacientes possui um bom nível de escolaridade e bom suporte financeiro.

\section{b. Período do estudo:}

Entre maio de 2015 e janeiro 2017.

\section{c. Amostragem:}

A amostra foi composta por 54 pacientes adultos. A convocação dos pacientes foi realizada de forma sistemática, ou seja, a pesquisadora no dia do ambulatório de HIV pegava a lista de pacientes do dia e chamava o primeiro nome da lista, sem conhecimento prévio de sua situação sorológica e clínica e o convidava para participar da pesquisa. Caso aceitasse era realizada a avaliação em outro dia e horário que fosse apropriado para o paciente (essa estratégia foi devida ao tempo necessário para realizar 
a avaliação, já que esta podia interferir na consulta média se fossem no mesmo dia), caso houvesse recusa, a pesquisadora chamava o segundo nome da lista e assim sucessivamente. Em um segundo momento a pesquisadora fez um outro convite, via ligação telefônica, aos pacientes que se negaram participar, e também àqueles que faltaram no dia agendado.

\section{d. Critérios de inclusão}

Pacientes com diagnóstico de infecção pelo HIV-1 acompanhados no ambulatório ADEE 3002, com idade igual ou superior a 18 anos e com escolaridade mínima de quatro anos, com indicação terapêutica para o uso de HAART, com acompanhamento regular (não faltante no último ano à consulta médica), que aceitassem participar da pesquisa durante o período da coleta.

\section{e. Critérios de exclusão}

- Diagnóstico concomitante de doenças neurológicas;

- Pacientes co-infectados, por exemplo, com HCV, HBV e HTLV;

- Uso de substâncias psicoativas (avaliado pela aplicação do questionário ASSIST, aplicado no participante que aceitasse participar da pesquisa);

- Incapacidade para compreender as instruções para a avaliação neurológica e aplicação dos testes incluídos no presente estudo;

-Não ter indicação para uso do antirretroviral;

-Ausência de consentimento para participar do estudo.

\section{f. Instrumentos}

Cada participante foi submetido à avaliação neuropsicológica composta pelas seguintes etapas:

a) Entrevista semiestruturada realizada com o participante para coleta de dados sociodemográficos e clínicos (Anexo I) e aplicação do questionário ASSIST para rastreio de uso de substâncias psicoativas (Anexo II);

b) Se o paciente não apresentou nenhum critério de exclusão, foi realizada a aplicação de testes e escalas padronizadas, com duração média de 1 h30min 
As informações demográficas e clínicas foram obtidas por meio de uma entrevista, utilizando-se um questionário estruturado. Dentre os dados demográficos e epidemiológicos avaliados podemos destacar: sexo, idade, status de emprego, estado civil; dados clínicos: grau de incapacidade motora, data de infecção pelo vírus e forma de transmissão. Adicionalmente foi realizada revisão dos prontuários para uma coleta de dados mais completa, incluindo informações dos exames laboratoriais (quantificação dos linfócitos T-CD4+, quantificação da carga viral do HIV-1 no sangue, glicose, hemoglobina, colesterol total, triglicérides, LDL, HDL e CPE). Foram considerados os resultados laboratoriais mais próximos à avaliação clínica (até 3 meses antes ou depois).

Foi aplicado também o Questionário Neurocognitivo Breve (Anexo III), que são três questões referentes à percepção de dificuldade de memória, atenção e resolução de problemas, com a possibilidade de três respostas: sim, às vezes e não. O Ministério da Saúde do Brasil recomenda que este questionário seja aplicado no momento do diagnóstico da infecção pelo HIV, antes do início da HAART; depois, anualmente e em pacientes com fatores de risco para HAND, a triagem pode ser realizada a intervalos de 6 meses $^{(20)}$ :

- Memória ("você tem perda de memória frequente? Esquece-se de eventos especiais ou reuniões, inclusive aquelas mais recentes? ");

- Lentificação psicomotora ("você sente que está mais lento quando pensa, planeja atividades ou resolve problemas? "); e/ou

- Atenção ("você tem dificuldades para prestar atenção, por ex., ao conversar, ler um jornal ou assistir a um filme?").

Foi aplicada a International HIV Dementia Scale (IHDS) (Anexo IV), que é uma escala utilizada para o rastreio de alterações neurocognitivas em pacientes infectados por HIV-1. Essa escala avalia agilidade motora, velocidade psicomotora e memória. A pontuação total da IHDS consiste na somatória das pontuações dos três domínios avaliados. A máxima pontuação possível é de 12. O diagnóstico de demência deve ser considerado em paciente com uma pontuação $\leq 10^{(20,54)}$.

Para avaliação das atividades de vida diária foi utilizada a Escala de Lawton (Lawton, Brody, 1969)(55), adaptada para o contexto brasileiro por Santos e Virtuoso Júnior (2008) ${ }^{(56)}$ (Anexo V). Este questionário é um instrumento de rápida e fácil aplicação, que avalia a capacidade de telefonar, viajar, fazer compras, preparar refeições, fazer trabalhos manuais domésticos, lavar e passar roupas, tomar remédios e cuidar das finanças, sendo seu resultado expresso através de três possibilidades: independência, dependência parcial (necessidade de algum auxílio na execução das tarefas) e dependência completa. Estudos indicam, no entanto, que fatores 
sociodemográficos, como idade, sexo, arranjo familiar e educação podem exercer influência sobre a capacidade funcional. A pontuação vai de 0 a 21 pontos, sendo: 0-7 pontos: dependência total, 8-20 pontos: dependência parcial e 21 pontos: independência. O resultado desta escala possibilitará a avaliação da condição de realização das tarefas diárias e auxiliar na classificação dos tipos de transtornos neurocognitivos leve ou maior, segundo DSM 5.

Para avaliação do estado de humor foi utilizada a "Escala de Depressão e Ansiedade Hospitalar" (HADS) (Anexo VI). A HADS é uma medida de autoavaliação de depressão e ansiedade amplamente utilizada em pacientes com doenças físicas, tanto no contexto hospitalar, como em pesquisa. Esta escala contém 14 questões do tipo múltipla escolha, sendo dividida em duas subescalas, para ansiedade e depressão, com sete itens cada. A pontuação global em cada subescala vai de 0 a 21 , o corte para depressão é a somatória $\geq 10$ pontos e para ansiedade $\geq 9$ pontos. Dentre suas características destacam-se: os conceitos de depressão e ansiedade ficam separados; não contempla os sintomas vegetativos; a compreensão de depressão é tida pelo conceito de anedonia; tem como destino detectar graus leves de transtornos afetivos em ambientes não psiquiátricos e a responder, o paciente deve levar em consideração como se sentiu durante a última semana. A HADS foi desenvolvida para ser aplicada a pacientes de serviços não psiquiátricos de hospital geral e de atenção primária (57), já tendo sido validado em nosso meio ${ }^{(58)}$.

Para avaliação do uso de substâncias psicoativas foi utilizado o instrumento denominado teste de triagem do envolvimento com álcool, tabaco e outras substâncias (ASSIST, pelas siglas em inglês: Alcohol, Smoking and Substance Involvement Screening Test). O teste, desenvolvido em $2002^{(59)}$, caracteriza-se por ser autoaplicável e consiste de 8 questões sobre o uso de nove classes de substâncias psicoativas (tabagismo, álcool, maconha, cocaína, estimulantes, sedativos, inalantes, alucinógenos e opiáceos). As questões abordam a frequência de uso, na vida e nos últimos 3 meses, problemas relacionados ao uso, preocupação a respeito do uso por parte de pessoas próximas ao usuário, prejuízo na execução de tarefas esperadas, tentativas malsucedidas de cessar ou reduzir o uso, sentimento de compulsão e uso por via injetável. Cada resposta corresponde a um escore, que varia de 0 a 4 , sendo que a soma total pode variar de 0 a 20. Considera-se a faixa de escore de 0 a 3, como indicativa de uso ocasional, de 4 a 15 , como indicativa de abuso e $\geq 16$, como sugestiva de dependência. Utilizamos a versão em português do ASSIST, validada por Henrique et al (2002) $)^{(60)}$. Os pacientes que apresentaram uma pontuação que sugeriu indicação de abuso ou dependência foram excluídos. 
Para a avaliação do suporte social foi utilizada a Escala de Suporte Social para Pessoas Vivendo com HIVIAids (Anexo VII); é um instrumento específico para pessoas soropositivas que explicita o suporte social percebido pelo paciente e o sentimento de satisfação. A escala Social Support Inventory for People Who are Positive or Have Aids foi construída e validada no Canadá pelos autores Renwick, Halpen, Rudman \& Friedland $(1999)^{(61)}$ e validada no Brasil por Seidl e Tróccoli $(2006)^{(39)}$. Este instrumento foi desenvolvido com base em estudos sobre o suporte social para a população em geral e para pessoas acometidas por condições médicas específicas, como HIV/aids. É composto de 24 itens, com escala de resposta tipo Likert de cinco pontos, podendo ser auto aplicado ou administrado mediante entrevista. Dividido em dois fatores: 1- suporte emocional- percepção e satisfação quanto à disponibilidade de escuta, atenção, informação, estima, companhia e apoio emocional em relação à soropositividade; 2 suporte instrumental - percepção e satisfação quanto à disponibilidade de apoio no manejo ou resolução de questões operacionais do tratamento ou do cuidado de saúde, de atividades práticas do cotidiano, de ajuda material e/ou financeira ${ }^{(39)}$.

Para a avaliação da adesão ao antirretroviral foi aplicado o "CEAT-VIH Questionário de avaliação da adesão ao tratamento antirretroviral" (Anexo VIII), que foi desenvolvido por Eduardo Remor $(2002)^{(62)}$ e validado para a versão brasileira por Remor, Milner-Moskovics e Preussler $(2007)^{(63)}$. O instrumento é constituído por 20 questões, a pontuação total é obtida pela soma de todos os itens, sendo o valor mínimo possível 17 e o valor máximo possível 89, quanto maior a pontuação, maior o grau de adesão ao tratamento(63).

A avaliação neuropsicológica estruturada tem um papel fundamental na identificação e diagnóstico de transtornos neurocognitivos associados ao HIV. Os testes utilizados nesse estudo foram todos recomendados pela literatura ${ }^{(21)}$.

Funções cognitivas avaliadas e testes utilizados:

1. Memória: Curto Prazo ou Operacional: subteste Dígitos de ordem direta e indireta da escala WAIS-III ${ }^{(64)}$ (Anexo IX); Episódica Auditiva: The Rey Auditoryverbal Learning test (RAVLT) (Anexo X) (Spreen et al 1998, Diniz et al, 2010)(65).

- Dígitos (WAIS III): Este subteste é composto de duas tarefas que são aplicadas uma independente da outra: Ordem Direta e Inversa. Em ambas as tarefas, o examinador, lê, em voz alta, uma série de sequências de números para o examinando. Para cada item da Ordem Direta, o examinando deverá repetir a sequência numérica na mesma ordem apresentada. Para cada item da Ordem Inversa, o examinando deverá 
repetir a sequência numérica na ordem contrária à apresentada pelo examinador. Função cognitiva avaliada: memória operacional e de trabalho, esta função está associada à estocagem das informações, flexibilidade mental, atenção ativa/ passiva e processamento de novas informações.

- Rey Auditory Learning Test (RAVLT): Este teste avalia uma grande diversidade de funções: memória episódica auditiva-verbal de curto e longo prazo, curva de aprendizagem, estratégias de aprendizagem, interferência proativa, presença de confabulação e de confusão em processos de memória, retenção de informações, e as diferenças entre a aprendizagem, recuperação e reconhecimento. O examinador lê uma lista de 15 palavras não relacionadas repetidas ao longo de cinco ensaios diferentes e pede para o examinando repetir as palavras que conseguir se lembrar, em qualquer ordem. Outra lista de 15 palavras não relacionadas é lida para o examinando e solicitado que o mesmo repita as palavras que conseguir se lembrar, em qualquer ordem. Em seguida é solicitado ao examinando que volte a repetir (as palavras que se lembrar) da lista original de 15 palavras e, em seguida, novamente após 30 minutos. Posteriormente, é lida para o examinando uma lista de 60 palavras, onde é solicitado que reconheça as 15 palavras da lista original.

2. Atencão/Velocidade de processamento de informação: subteste de Códigos da escala WAIS-III ${ }^{(64)}$ (Anexo XI).

- Códigos (WAIS III): Neste subteste, o examinando deve copiar símbolos simples que estão associados com números. Usando uma chave, o examinando desenha símbolos sob o número correspondente. A pontuação é determinada pelo número de símbolos escritos corretamente, dentro do tempo limite de 120 segundos. O objetivo é medir a velocidade de informação (tempo requerido para processar as informações), memória de curto prazo, aprendizado, percepção visual, coordenação motora e visual, amplitude visual, atenção e motivação. Avalia o tempo que o cérebro requer para processar uma informação.

\section{Funcão executiva - Fluência Verbal cateqórica: FAS e Animais ${ }^{(66)}$ (Anexo XII)}

- FAS: Neste teste é solicitado ao examinando dizer o maior número possível de palavras, num período de 60 segundos, para cada uma das letras ( $F, A$ e S). O escore total é dado mediante a soma de todas as palavras corretas iniciadas com as três letras. 
Gírias e palavras estrangeiras são consideradas corretas. Nomes próprios e palavras repetidas não são considerados.

- Animais: Neste teste é solicitado ao examinando que fale o maior número de animais em um minuto. O escore total é dado mediante a soma de das palavras corretas. Nome de animais repetidos não são considerados.

Estes dois testes avaliam a função executiva, que é o conjunto de habilidades, que de forma integrada, possibilitam ao indivíduo direcionar comportamentos a objetivos.

\section{Atencão/ Funcão Executiva: Trail Making Test $\mathbf{A}$ and $\mathbf{B}^{(67)}$ (Anexo XIII)}

- Teste de Trilhas (Formas A e B): Para a forma A o examinando é instruído a traçar rapidamente uma linha que ligue os círculos numerados de 1 a 25, na ordem crescente e sem levantar o lápis do papel. A forma A avalia atenção sustentada que se refere à capacidade de prestar atenção a um determinado campo de estimulação por período prolongado, competindo com outros estímulos e de manter o foco no estímulo- alvo. Para a forma $B$, o examinando é instruído a traçar rapidamente uma linha entre os círculos numerados de 1 a 13 e letras de A até L, ou seja, 1-A, 2-B, 3-C e assim por diante, obedecendo à sequência dos números e letras de maneira crescente, mas alternando entre si. A forma $\mathrm{B}$ avalia $\mathrm{a}$ atenção dividida, que se refere à capacidade de manter a atenção em estímulos diferentes para executar duas ou mais tarefas simultaneamente.

5. Habilidade motora: Grooved Pegboard (Maj et al.,1994) ${ }^{(68)}$ (Anexo XIV).

- Grooved Pegboard: O teste é constituído por uma placa de metal com uma matriz de 25 buracos posicionados aleatoriamente e bastonetes de ferro com ranhuras. Cada bastonete deve ser rodado para coincidir com o buraco, antes de poderem ser inseridos. É solicitado ao examinando que coloque os bastonetes nos buracos, primeiro com a mão dominante e posteriormente com a mão não dominante o mais rápido possível. O objetivo é avaliar a coordenação e velocidade viso-motora, portanto, este teste requer integração sensório-motor e um alto nível de processamento motor. É considerada uma tarefa motora mais complexa do que outros, como o Finger Tapping Test, e é mais sensível à velocidade psicomotora.

Para a correção dos testes neuropsicológicos, foi calculado o escore bruto (pontuação total feita pelo paciente em cada teste) para obtenção do percentil e 
classificação do desempenho. Nos subtestes da escala WAIS III após o escore bruto, a tabela do manual fornece o ponto ponderado que é transformado em percentil e classificação. Nos demais testes são calculados os Zs escores, que é a pontuação do paciente menos a média da população normativa dividida pelo desvio padrão. Após a obtenção do Z escore é encontrado percentil e a classificação. Cada teste tem sua tabela normativa que pode ser dividida em idade e ou escolaridade. 


\section{Análise Estatística}

Os dados coletados foram inseridos em banco de dados construído em programa estatístico (SPSS versão 16.0) e tratados por meio de estatística descritiva, com cálculos de percentuais, médias e frequências.

Para comparação do desempenho neuropsicológico entre grupos, foram realizadas análises de variância para amostras independentes com 1 fator (one-way ANOVA) para identificação de possíveis covariáveis associadas ao desempenho neuropsicológico dos participantes (sexo, idade, escolaridade e depressão). Após o estabelecimento das covariáveis, foi realizada análise de três grupos (ANCOVA) com o objetivo de eliminar o efeito devido estas covariáveis, reduzindo, a variância do erro. Quando encontrado diferença estatística foi utilizado o ps-teste de Bonferroni para identificar quais os pares de grupos que diferem.

Todas as análises quantitativas foram realizadas com o programa estatístico SPSS (16.0) ${ }^{(69)}$ e $p<0,05$ foi estabelecido como nível de significância. 


\section{Aspectos éticos}

A realização do estudo se deu após a assinatura do Termo de Consentimento Livre e Esclarecido (TCLE) (Anexo XV). Neste documento foram apresentados não apenas os objetivos do estudo, como também os instrumentos da pesquisa. Durante todo o período do estudo foi garantida a liberdade aos participantes em desistir de participar da pesquisa a qualquer momento, livres de prejuízos à continuidade de seu tratamento na Instituição. 


\section{Resultados}

\section{a. Perfil Sociodemográfico e clínico}

\subsubsection{Identificação dos Sujeitos}

Para se chegar ao total da amostra foram abordados 201 pacientes. Desses, 147 foram excluídos, sendo os motivos especificados na Figura 1. Finalmente foram incluídos 54 pacientes.

Características dos Participantes

201 pacientes abordados

147 excluídos

6 - desacordo com critérios de inclusão

57 - faltaram aos agendamentos 30 - não foi possível contato telefônico para agendamento 54 - não tiveram interesse em participar

54 incluídos no estudo

Figura 1: Fluxograma dos pacientes entrevistados e incluídos na amostra

Os participantes, predominantemente, foram do sexo masculino $(70,4 \%)$, solteiros (50\%), idade média de 45,11 anos (dp $\pm 12,03)$, escolaridade média de 12,54 anos $(d p \pm 4,02)$ e o mecanismo de transmissão mais frequente foi a via sexual $(77,8 \%)$ A maioria dos participantes residiam na cidade de São Paulo $(61,1 \%)$, relatou estarem empregados (72,22\%), com renda mensal média de $\mathrm{R} \$ 2.796,96$ ( $\mathrm{dp} \pm$ 2771,912).

Os critérios para a classificação de HAND indicaram 22 participantes $(40,74 \%)$ com desempenho cognitivo normal, 18 participantes (33,33\%) com ANI, 14 participantes $(25,92 \%)$ com MND e nenhum diagnóstico para HAD. Foi encontrada significância estatística na associação entre classificação de HAND e a Escala de Atividade de Vida Diária de Lawton (AVD) ( $p=0,00)$, e os resultados obtidos por autorrelato mostraram que os pacientes com MND apresentam maior dependência parcial em sua rotina, e os pacientes sem alteração neurocognitiva se percebem mais independentes. A tabela 1 
apresenta as características demográficas e clínicas dos participantes, em função da classificação da HAND.

Tabela 1 - Distribuição dos pacientes portadores de HIV-1 sem alteração neurocognitiva, ANI e MND, segundo características sociodemográficas. Resultados baseados no autorrelato.

\begin{tabular}{|c|c|c|c|c|c|}
\hline Variável & Categoria & $\begin{array}{c}\text { Sem alteração } \\
\text { (22) }\end{array}$ & $\begin{array}{l}\text { ANI } \\
\text { (18) }\end{array}$ & $\begin{array}{l}\text { MND } \\
(14)\end{array}$ & $\mathbf{P}$ \\
\hline \multirow[t]{2}{*}{ Sexo } & Masculino & $18(81,81 \%)$ & $12(70,6 \%)$ & $7(50 \%)$ & 0,12 \\
\hline & Feminino & $4(18,18 \%)$ & $5(29,41 \%)$ & $7(50 \%)$ & \\
\hline Idade* & & $45,70( \pm 11,7)$ & $43,72( \pm 12,7)$ & $46( \pm 12,3)$ & \\
\hline Escolaridade* & & $13,20( \pm 4,0)$ & $12,7( \pm 4,0)$ & $11,3( \pm 4,1)$ & 0,37 \\
\hline \multirow[t]{5}{*}{ Estado Civil } & Solteiro (a) & $15(68,1 \%)$ & $9(50 \%)$ & $3(21,4 \%)$ & 0,31 \\
\hline & Casado (a) & $3(13,6 \%)$ & $4(22,2 \%)$ & $7(50 \%)$ & \\
\hline & Divorciado (a) & $1(4,5 \%)$ & 0 & $1(7,1 \%)$ & \\
\hline & Relação Estável & $2(9 \%)$ & $3(16,6 \%)$ & $2(14,3 \%)$ & \\
\hline & Viúvo (a) & $1(4,5 \%)$ & $2(11,1 \%)$ & $1(7,1 \%)$ & \\
\hline \multirow[t]{5}{*}{ Ocupação } & Estudante & 0 & 0 & 0 & 0,60 \\
\hline & Do Lar & $1(4,3 \%)$ & 0 & 0 & \\
\hline & Empregado & $17(73,9 \%)$ & $12(66,6 \%)$ & $10(58,8 \%)$ & \\
\hline & Desempregado & $2(8,7 \%)$ & $4(22,2 \%)$ & $5(29,4 \%)$ & \\
\hline & Aposentado & $3(13 \%)$ & $2(11,1 \%)$ & $2(11,7 \%)$ & \\
\hline \multirow[t]{3}{*}{ AVD's } & Dependência & 0 & 0 & 0 & \\
\hline & Parcial & $2(9 \%)$ & $3(16,6 \%)$ & $12(85,7 \%)$ & 0,00 \\
\hline & Independência & $20(90,9 \%)$ & $15(83,3 \%)$ & $2(14,3 \%)$ & \\
\hline \multicolumn{6}{|l|}{ Transmissão } \\
\hline & Relação sexual & $16(72,7 \%)$ & $13(72,2 \%)$ & $13(92,8 \%)$ & 0,42 \\
\hline & Vertical & 0 & $1(5,5 \%)$ & 0 & \\
\hline & Sangue & $1(4,5 \%)$ & 0 & 0 & \\
\hline & Drogas endovenosas & 0 & $1(5,5 \%)$ & 0 & \\
\hline & Outros & $2(9 \%)$ & $1(5,5 \%)$ & 0 & \\
\hline & Não sabe & $3(13,6 \%)$ & $2(11,1 \%)$ & $1(7,1 \%)$ & \\
\hline
\end{tabular}

*Significa $\bar{x}(D P), p<0,05$. HAND: Academia Americana de Neurologia de 2007 - Critérios de Frascati. AVD: Escala de Atividade de Vida Diária de Lawton

O impacto da progressão dos sintomas pode ser observado no questionário das atividades de vida diária. A maioria dos pacientes com MND apresentou dependência 
parcial (85,7\% - tabela 1) e impacto nas funções trabalho doméstico e uso de medicamentos, quando comparado com o grupo de pacientes sem alterações, conforme tabela 2 abaixo.

Tabela 2: Distribuição de pacientes com HIV-1 sem sintomas, com ANI e MND, segundo critérios da Escala de Atividade de Vida Diária de Lawton. Resultados baseados no autorrelato.

\begin{tabular}{|c|c|c|c|c|c|c|c|}
\hline Variável & & $\begin{array}{l}\text { Sem alteração } \\
\text { (22) }\end{array}$ & $\begin{array}{l}\text { ANI } \\
\text { (18) }\end{array}$ & $\begin{array}{l}\text { MND } \\
\text { (14) }\end{array}$ & $\begin{array}{l}\mathrm{P} \\
\text { Hoc }\end{array}$ & Post & $\mathbf{P}$ \\
\hline \multirow[t]{3}{*}{ 1. Uso do telefone } & Incapaz & 0 & 0 & 0 & & & \\
\hline & $\begin{array}{l}\text { Com } \\
\text { assistência }\end{array}$ & 0 & 0 & 0 & & & \\
\hline & $\begin{array}{l}\text { Sem } \\
\text { assistência }\end{array}$ & $22(100 \%)$ & $18(100 \%)$ & $13(100 \%)$ & & & \\
\hline \multirow[t]{3}{*}{ 2. Viagens } & Incapaz & 0 & 0 & 0 & 0,21 & & \\
\hline & $\begin{array}{l}\text { Com } \\
\text { companhia }\end{array}$ & 0 & 0 & $1(7,7 \%)$ & & & \\
\hline & Sozinho & $22(100 \%)$ & $18(100 \%)$ & $\begin{array}{l}12 \\
(92,3 \%)\end{array}$ & & & \\
\hline \multirow[t]{3}{*}{ 3. Compras } & Incapaz & 0 & 0 & 0 & 0,21 & & \\
\hline & $\begin{array}{l}\text { Com } \\
\text { companhia }\end{array}$ & 0 & 0 & $1(7,7 \%)$ & & & \\
\hline & Sozinho & $22(100 \%)$ & $18(100 \%)$ & $\begin{array}{l}12 \\
(92,3 \%)\end{array}$ & & & \\
\hline \multirow[t]{3}{*}{ 4.Cozinhar } & Incapaz & 0 & 0 & 0 & 0,17 & & \\
\hline & Pequenas & 0 & $1(5,5 \%)$ & $2(15,3 \%)$ & & & \\
\hline & Completas & $22(100 \%)$ & $17(94,4)$ & $\begin{array}{l}11 \\
(84,6 \%)\end{array}$ & & & \\
\hline \multirow[t]{3}{*}{ 5.Limpar a casa } & Incapaz & 0 & 0 & 0 & 0,007 & & \\
\hline & $\begin{array}{l}\text { Trabalhos } \\
\text { leves }\end{array}$ & $1(4,5 \%)$ & $1(5,5 \%)$ & $5(38,4 \%)$ & & & \\
\hline & Pesados & $21(95,4 \%)$ & $17(94,4)$ & $8(61,5 \%)$ & & & \\
\hline \multirow[t]{3}{*}{ 6. Uso do remédio } & $\begin{array}{l}\text { Não } \\
\text { sozinho }\end{array}$ & 0 & $1(5,5 \%)$ & 0 & 0,00 & B e C & \\
\hline & Lembretes & 0 & 0 & $9(69,2 \%)$ & & & \\
\hline & $\begin{array}{l}\text { Sem } \\
\text { assistência }\end{array}$ & $22(100 \%)$ & $\begin{array}{l}17 \\
(94,4 \%)\end{array}$ & $4(36,7 \%)$ & & & \\
\hline 7.Lidar c/ dinheiro & $\begin{array}{l}\text { Incapaz } \\
\text { Com auxílio } \\
\text { Sem auxílio }\end{array}$ & $\begin{array}{l}0 \\
0 \\
22(100 \%)\end{array}$ & $\begin{array}{l}0 \\
0 \\
18(100 \%)\end{array}$ & $\begin{array}{l}0 \\
0 \\
13(100 \%)\end{array}$ & & & \\
\hline
\end{tabular}

p<0,05. HAND: Academia Americana de Neurologia de 2007 - Critérios de Frascati. AVD: Escala de Atividade de Vida Diária de Lawton, A: Sem alteração x ANI; B: Sem alteração x MND; C: ANI x MND

\subsubsection{Identificações Clínicas}


A média de tempo, em anos, sobre a condição sorológica positiva para HIV-1 entre os pacientes foi de 15 anos $(d p \pm 8,49)$ e a grande maioria dos pacientes não tiveram episódios de doenças oportunistas (70,40\%). Os valores das Células T CD4 apresentam a média de $639 \mathrm{~mm}^{3}(\mathrm{dp} \pm 294)$ e 80,8\% da amostra estava com carga viral indetectável (< 40 cópias/ml).

Com relação a toda análise clínica laboratorial, não foi encontrada significância estatística na associação entre as variáveis em função da classificação de HAND, como mostra a tabela 3.

Tabela 3: Distribuição dos dados laboratoriais através das categorias HAND.

\begin{tabular}{|c|c|c|c|c|}
\hline Variáveis & $\begin{array}{c}\text { Sem alteração } \\
\text { (22) }\end{array}$ & $\begin{array}{l}\text { ANI } \\
\text { (18) }\end{array}$ & $\begin{array}{c}\text { MND } \\
(14)\end{array}$ & $\mathbf{P}$ \\
\hline Células T CD4 & $556( \pm 299)$ & $739( \pm 304)$ & $713( \pm 299)$ & 0,17 \\
\hline $\begin{array}{l}\text { Carga viral* } \\
\text { Indetectável } \\
\text { Detectável }\end{array}$ & $\begin{array}{c}17(77,2 \%) \\
5(22,7 \%)\end{array}$ & $\begin{array}{c}15(83,3 \%) \\
3(16,6 \%)\end{array}$ & $\begin{array}{c}10(71,4 \%) \\
4(28,6 \%)\end{array}$ & 0,78 \\
\hline Glicose & $98( \pm 19)$ & $95( \pm 13,6)$ & $92( \pm 6,7)$ & 0,53 \\
\hline Hemoglobina & $14,4( \pm 1,3)$ & $14,5( \pm 1,7)$ & $13,9( \pm 1,1)$ & 0,59 \\
\hline Colesterol total & $177,2( \pm 35)$ & $183,4( \pm 52,8)$ & $176( \pm 26,5)$ & 0,99 \\
\hline Triglicérides & $128( \pm 72,8)$ & $130( \pm 9,71)$ & $141,1( \pm 83,1)$ & 0,80 \\
\hline LDL & $109,6( \pm 30,4)$ & $114,1( \pm 39,8)$ & $106,3( \pm 18,9)$ & 0,95 \\
\hline HDL & $43,2( \pm 11,8)$ & $40( \pm 11,9)$ & $43,6( \pm 10,9)$ & 0,39 \\
\hline
\end{tabular}

*Significa: $n$ (\%). p<0,05. Carga viral indetectável < 40 cópias/ml. HAND: Academia Americana de Neurologia de 2007 - Critérios de Frascati.

A tabela 4 apresenta os valores do escore de penetração do esquema antirretroviral no sistema nervoso central (CPE) e uso da medicação Efavirenz relacionados à classificação de HAND. Estas variáveis também não apresentaram diferenças estatísticas na população estudada. 
Tabela 4: Distribuição dos valores CPE e uso do Efavirenz através das categorias HAND.

\begin{tabular}{lcccc}
\hline Variáveis & $\begin{array}{c}\text { Sem alteração } \\
(\mathbf{2 2})\end{array}$ & $\begin{array}{c}\text { ANI } \\
(\mathbf{1 8 )}\end{array}$ & $\begin{array}{c}\text { MND } \\
\mathbf{( 1 4 )}\end{array}$ & P \\
\hline CPE* $^{\text {Efavirenz, }}$ & $6( \pm 0,9)$ & $5,9( \pm 1,6)$ & $5,8( \pm 1)$ & 0,87 \\
Em uso & & & \\
Não faz uso & $14(63,6 \%)$ & $8(44,4 \%)$ & $6(42,8 \%)$ & 0,36 \\
& $8(36,3 \%)$ & $10(55,5 \%)$ & $8(57,1 \%)$ & \\
\hline
\end{tabular}

*Significa $\bar{x}(D P)$. CPE, CNS penetration effectiveness. $\mathrm{p}<0,05$. HAND: Academia Americana de Neurologia de 2007 - Critérios de Frascati.

\subsection{Avaliação do Estado de Humor, Suporte Social e Adesão a HAART}

Ao se analisar a classificação das alterações neurocognitivas com os resultados das escalas de Ansiedade e Depressão, Suporte Social e Adesão ao Tratamento, os valores obtidos não foram suficientes para expressar significância estatística, ou seja, não foi possível observar diferenças entre as médias de cada escala quando comparado aos grupos de pacientes. A tabela 5 apresenta os resultados da adesão, alterações emocionais e suporte social.

Tabela 5 - Variáveis emocionais, adesão a HAART e suporte social dos pacientes avaliados através das categorias HAND.

\begin{tabular}{|c|c|c|c|c|}
\hline Escalas & $\begin{array}{c}\text { Sem alteração } \\
\text { (22) }\end{array}$ & $\begin{array}{l}\text { ANI } \\
(18)\end{array}$ & $\begin{array}{l}\text { MND } \\
(14)\end{array}$ & $P$ \\
\hline HAD A & $5,9( \pm 4,3)$ & $5,9( \pm 5)$ & $8,9( \pm 5,4)$ & 0,15 \\
\hline HAD D & $4,5( \pm 3,6)$ & $3,9( \pm 4,1)$ & $7,2( \pm 4,1)$ & 0,06 \\
\hline CEAT & $1,4( \pm 0,7)$ & $1,2( \pm 0,7)$ & $1( \pm 0,7)$ & 0,42 \\
\hline SS Instrumental & $42,5( \pm 11,7)$ & $44,7( \pm 11,3)$ & $42,6( \pm 11,5)$ & 0,96 \\
\hline SS Emocional & $46( \pm 11)$ & $45,7( \pm 10,3)$ & $40,6( \pm 10,6)$ & 0,34 \\
\hline
\end{tabular}

$\bar{x}(\overline{D P})$. p<0,05. HAD A e D, Escala de Depressão e Ansiedade Hospitalar; CEAT, Questionário de avaliação da adesão ao tratamento antirretroviral; Suporte Social Instrumental e Emocional, Escala de Suporte Social para Pessoas Vivendo com HIVIAids. HAND: Academia Americana de Neurologia de 2007 - Critérios de Frascati. 


\subsection{Avaliação Neuropsicológica}

A análise dos resultados de autorrelato do Questionário Neurocognitivo Breve com as classificações de HAND mostrou significância estatística na percepção subjetiva das variáveis alteração na memória $(p<0,01)$ e lentificação do pensamento $(p=0,01)$, bem como diferença entre os grupos na análise Post Hoc, ou seja, os pacientes com a forma MND relataram mais queixas de memória e pensamento com relação aos demais pacientes dos outros dois grupos. Os resultados são apresentados na tabela 6.

Tabela 6- Questionário Neurocognitivo Breve dos pacientes avaliados através das categorias HAND: resultados baseados no autorrelato dos pacientes.

\begin{tabular}{|c|c|c|c|c|c|}
\hline Variável & $\begin{array}{c}\text { Sem } \\
\text { alteração } \\
(22)\end{array}$ & $\begin{array}{l}\text { ANI } \\
\text { (18) }\end{array}$ & $\begin{array}{l}\text { MND } \\
(14)\end{array}$ & $\mathbf{p}$ & Post Hoc \\
\hline $\begin{array}{l}\text { Memória } \\
\text { Sim, definitivamente } \\
\text { Sim, as vezes } \\
\text { Não } \\
\text { Lentificação do } \\
\text { Pensamento } \\
\text { Sim, definitivamente } \\
\text { Sim, as vezes } \\
\text { Não } \\
\text { Atenção } \\
\text { Sim, definitivamente } \\
\text { Sim, as vezes } \\
\text { Não }\end{array}$ & $\begin{array}{c}1(4,5 \%) \\
13(59 \%) \\
8(36,3 \%) \\
2(9,1 \%) \\
10(45,4 \%) \\
10(45,4 \%) \\
3(13,6 \%) \\
9(40,9 \%) \\
10(45,4 \%)\end{array}$ & $\begin{array}{l}2(11,1 \%) \\
8(44,4 \%) \\
8(44,4 \%) \\
2(11,1 \%) \\
8(44,4 \%) \\
8(44,4 \%) \\
3(16,6 \%) \\
7(38,9 \%) \\
8(44,4 \%)\end{array}$ & $\begin{array}{c}4(28,6 \%) \\
10(71,4 \%) \\
0 \\
\\
5(35,7 \%) \\
8(57,1 \%) \\
1(7,14 \%) \\
5(35,7 \%) \\
7(50 \%) \\
2(14,3 \%)\end{array}$ & $0,01 *$ & B e C \\
\hline
\end{tabular}

A análise do desempenho de cada teste neuropsicológico mostrou que houve significância estatística e diferenças significativas entre os grupos na função neuropsicológica Memória, ou seja, os pacientes com a forma MND apresentaram maiores prejuízos nessa função quando comparado aos demais pacientes. A função cognitiva Atenção, mais precisamente Atenção Alternada, apresentou significância estatística, porém não foi observada diferença entre os grupos quando feita a análise Post Hoc. Dessa forma, o grupo sem prejuízo cognitivo teve desempenho superior aos outros dois grupos no teste Trail Making Test B. A tabela 7 apresenta os resultados para cada um dos grupos, bem como as estatísticas inferenciais e os valores de significância. 
Tabela 7 - Distribuição dos valores de cada teste da Avaliação Neuropsicológica através das categorias HAND

\begin{tabular}{|c|c|c|c|c|c|}
\hline Testes & $\begin{array}{c}\text { Sem alteração } \\
\text { (22) }\end{array}$ & $\begin{array}{l}\text { ANI } \\
(18)\end{array}$ & $\begin{array}{l}\text { MND } \\
(14)\end{array}$ & $\mathbf{P}$ & Post Hoc \\
\hline \multicolumn{6}{|l|}{ Memória } \\
\hline Digitos & $11,7( \pm 4,2)$ & $12( \pm 4)$ & $9,9( \pm 3,1)$ & 0,28 & \\
\hline RAVLT - Im & $45,3( \pm 9)$ & $42,2( \pm 7,5)$ & $35,4( \pm 9,8)$ & $0,01^{*}$ & $B$ e $C$ \\
\hline RAVLT - PI & $9,4( \pm 3,1)$ & $8,4( \pm 2,3)$ & $7,1( \pm 2,5)$ & 0,06 & \\
\hline RAVLT - Tr & $9,4( \pm 2,4)$ & $8,1( \pm 2,5)$ & $6,6( \pm 3)$ & $0,01^{*}$ & $\mathrm{~B}$ e $\mathrm{C}$ \\
\hline $\begin{array}{l}\text { RAVLT - Rc } \\
\text { Atenção }\end{array}$ & \multicolumn{5}{|c|}{ Atenção } \\
\hline Trail A & $29,7( \pm 14,9)$ & $37,4( \pm 16,5)$ & $44,4( \pm 26,8)$ & 0,08 & \\
\hline Trail B & $62( \pm 30,1)$ & $98,9( \pm 45,2)$ & $126,4( \pm 95)$ & $<0,01^{*}$ & \\
\hline \multicolumn{5}{|c|}{ Veloc. de Proc. } & \\
\hline \multicolumn{6}{|l|}{ Func. Exe. } \\
\hline FAZ & $30,8( \pm 12,6)$ & $32,7( \pm 11,8)$ & $23,6( \pm 12,7)$ & 0,11 & \\
\hline Animais & $16,2( \pm 5,5)$ & $17,1( \pm 4,6)$ & $14( \pm 6,9)$ & 0,30 & \\
\hline \multicolumn{6}{|c|}{ Esc. de rastreio } \\
\hline IHDS & $9,2( \pm 3)$ & $10,1( \pm 2,3)$ & $8,7( \pm 3,3)$ & 0,41 & \\
\hline \multicolumn{6}{|c|}{ Vel. Motora } \\
\hline $\mathrm{Gr}-\mathrm{MD}$ & $62,2( \pm 26,8)$ & $69( \pm 24,6)$ & $72,2( \pm 35,4)$ & 0,56 & \\
\hline Gr- MND & $75,55( \pm 31,93)$ & $74,6( \pm 22)$ & $81,93( \pm 39,5)$ & 0,71 & \\
\hline
\end{tabular}

$\bar{x}(\overline{D P}) . \mathrm{p}<0,05 . \mathrm{A}$ (inalterado $\times \mathrm{ANI}), \mathrm{B}$ (inalterado $\times \mathrm{MND}), \mathrm{C}(\mathrm{ANI} \times \mathrm{MND})$. Digitos e Código - subestes WAIS - III; RAVLT, The Rey Auditory-Verbal Learning Test; Trail, Trail Making Test $A$ and B; IHDS, International HIV Dementia Scale; Gr, Grooved Pegboard. HAND: Academia Americana de Neurologia de 2007 - Critérios de Frascati. A: Sem alteração x ANI; B: Sem alteração x MND; C: ANI x MND 


\section{Discussão}

Com relação ao nosso estudo, encontramos uma alta prevalência de HAND (60\%), sendo 18 participantes (33,33\%) com ANI e 14 participantes (25,92\%) com MND, não havendo nenhum resultado de demência na amostra analisada.

A origem de muitas alterações cognitivas não foi completamente compreendida. Entretanto, muitos especialistas concordam que comprometimentos cognitivos, assim como outras doenças crônicas, se desenvolvem como resultado de vários fatores e não apenas de uma única causa específica. No caso dos pacientes infectados pelo HIV-1, o interesse por alterações cognitivas começou logo no início da epidemia da Aids após vários relatos descrevendo a presença de uma demência subcortical progressiva com componentes cognitivos, motores e comportamentais, levando à morte em poucos meses $^{(11)}$.

Alguns autores defendem que a presença de alterações neurocognitivas seria devido à má distribuição dos antirretrovirais no SNC, o que levaria a queda de concentração dos fármacos no LCR e com isso não impediria a replicação do vírus de tipo selvagem. Desta forma, esta baixa distribuição dos remédios explicaria porque alguns pacientes apresentam níveis detectáveis do vírus no LCR mesmo quando indetectável no sangue(3).

Independente dos pesquisadores ainda não terem um consenso sobre a origem das alterações, outros mecanismos patogenéticos de estrema importância são o legado do dano no SNC devido ao HIV mantido antes do início da TARV, a neurotoxicidade dos antirretrovirais, os efeitos indiretos de doenças oportunistas e a presença de sintomas depressivos $^{(3,4,31)}$.

No Brasil existem poucos dados sobre a prevalência de HAND, e a maioria dos estudos utilizaram uma bateria de avaliação neuropsicológica menos complexa que a utilizada neste estudo. Estudos anteriores realizados em algumas regiões brasileiras mostraram essa prevalência de HAND variando entre 4,6\% e 52,4\%(31,32,34).

Essa variabilidade das prevalências encontradas no Brasil, inclusive do presente estudo, pode ser explicada pela diversidade de instrumentos utilizados, pelos critérios utilizados para se definir HAND, pelo tamanho da população estudada ou pela ausência de variáveis de controle capazes de influenciar os resultados dos exames neuropsicológicos, como o nível de escolaridade, o desemprego e depressão. Características regionais também parecem ser importantes, incluindo o tipo de comorbidade existente e o subtipo do HIV prevalente ${ }^{(37)}$. 
Após a análise multivariada, foi possível verificar o impacto da progressão dos sintomas pelo Questionário de autorrelato Escala de Lawton, que avalia as Atividades de Vida Diária. A maioria dos pacientes com MND apresentaram dependência parcial $(85,7 \%)$ e impacto nas funções trabalho doméstico e uso de medicamentos, quando comparado com o grupo de pacientes sem alterações. Os estudos que embasaram a padronização da escala para a população brasileira indicaram que a variável idade, sexo, arranjo familiar e educação podem exercer influência sobre a capacidade funcional(56). O nosso estudo não apresentou significância estatística nesses fatores sociodemográficos. Uma possível explicação para esse impacto negativo na amostra analisada seria que o comprometimento cognitivo prejudica a autonomia na realização das tarefas do cotidiano e o autocuidado ${ }^{(6,20)}$.

A análise dos resultados do Questionário Neurocognitivo Breve, também apresentou uma significância estatística diante da percepção subjetiva do paciente com relação à variável alteração na memória e lentificação do pensamento, havendo diferenças entre os grupos na análise Post Hoc, mostrando que os pacientes com a forma MND apresentaram mais queixas de memória e de pensamento com relação aos demais pacientes. Esses danos podem indicar que vale a pena fazer essas perguntas em consultas e encaminhar para avaliação, para que possa diferenciar depressão de HAND.

Em um estudo na Suíça que avaliou uma coorte de pacientes semelhante à deste estudo com relação à carga viral indetectável, ausência de doença oportunista e de depressão maior, Simioni et al. ${ }^{(24)}$ utilizaram uma complexa bateria de exames neuropsicológicos em pacientes HIV, e avaliaram as funções cognitivas de 50 pacientes com autorrelato de queixa e 50 pacientes não queixosos. A prevalência de HANDs foi de $84 \%$ entre aqueles que tinham a percepção de queixa cognitiva (24\% ANI, 52\% MND e $8 \%$ HAD) e $64 \%$ entre os que não tiveram auto percepção de dificuldades na vida diária $(60 \% \mathrm{ANI})$.

Mesmo sabendo que os pacientes não queixosos não foram $100 \%$ imunes ao diagnóstico de alteração neurocognitiva, o presente estudo vai de encontro à importância de a equipe de saúde levar em consideração a fala do paciente durante todo o processo de tratamento. A razão seria que as queixas cognitivas são preditivas de comprometimento real, e este interfere nos comportamentos de promoção de saúde e na vida independente do paciente ${ }^{(6)}$.

A maioria dos estudos utilizados na revisão de literatura deste trabalho apresentaram associação significativa com o comprometimento neurocognitivo nas variáveis idade, sexo feminino, escolaridade, presença de doenças oportunistas, células 
T CD4 $<200 \mathrm{~mm}^{3}$ e carga viral $>100.000$ cópias $/ \mathrm{ml}^{(4,6,31,32,34)}$. O presente estudo não apresentou significância diante desses dados, e isso pode ser explicado pelo tamanho da amostra estudada, bem como suas características. Entretanto, os fatores preditivos de HAND, como baixo número de células T CD4+ e alto nível de carga viral plasmática, são mais frequentes em populações vulneráveis, em que o diagnóstico é muitas vezes atrasado por falta de acesso aos serviços de saúde e/ou desconhecimento sobre a infecção pelo $\mathrm{HIV}^{(37)}$, sendo este perfil populacional diferente da coorte deste estudo.

Muitos estudos também apontam que o diagnóstico de diabetes, hipertensão e hipercolesterolemia podem ser fatores de risco para o desenvolvimento de $\operatorname{HAND}^{(9,28,35,37) ;}$ porém, a análise destes parâmetros não apresentou significância estatística em nossa coorte. Isto pode ser explicado tanto devido ao tamanho da amostra não ser suficiente para alcançar este resultado, como pelo fato destas comorbidades serem tratadas adequadamente. É importante ressaltar que a análise laboratorial de cada exame mostrou que a maioria dos pacientes apresentaram resultados que estão dentro do intervalo esperado para a ausência de risco.

A elevada prevalência de HAND observada neste estudo poderia ser explicada pela replicação viral persistente no SNC, independente do controle virológico sistêmico. Uma das variáveis postuladas para este fenômeno é a disponibilidade de drogas com diferente penetração no SNC. Contudo, não identificamos diferenças estatísticas entre o CPE e o comprometimento neurocognitivo. Além do mais, a evidência disponível que fundamenta o benefício de esquemas com melhor penetração no SNC é controversa, existindo recomendações conflitantes ${ }^{(3,7,11,19)}$.

Além do já descrito neste estudo, a alta frequência de sintomas de depressão e ansiedade em pacientes portadores de HIV-1 ${ }^{(3,26,34)}$ pode também ser explicada se traduzirmos o fato deste sujeito estar infectado por um vírus que traz a perda do corpo saudável, a possível ou real perda da autonomia, da independência, dos vínculos sociais, afetivos e ocupacionais. Essa sensação pode ocasionar uma doença degenerativa trazida pela sorologia positiva, que implica na possibilidade de não corresponder às expectativas pessoais, da família e da sociedade, concorrendo para a frustração e interrupção de um projeto de vida pessoal, familiar e profissional $(4,39,41)$.

Este estudo não apresentou significância estatística ao analisar a presença de sintomas de humor/afetivo, havendo a possibilidade deste resultado ter sido influenciado pelo tamanho da amostra. Porém, é importante ressaltar que para uma melhor garantia de que não houvesse outra causa óbvia do que o próprio HIV para explicar a presença de HAND, tentamos minimizar possíveis fatores de confusão não registrando pacientes 
com depressão maior, toxicodependência ativa ou infecção oportunista. Estas variáveis podem apresentar sintomas semelhantes aos de alterações neurocognitivas, mascarando o diagnóstico.

Entretanto, mesmo não havendo significância, os resultados obtidos mostraram que os pacientes com MND apresentaram uma maior presença de sintomas de ansiedade e depressão quando comparado aos pacientes dos outros dois grupos. Uma explicação pertinente refere-se ao fato desses sintomas não serem exclusivos do transtorno psiquiátrico depressão, sendo muito presente também no comprometimento cognitivo $^{(4,41,43,44)}$. No mais, pacientes com a forma MND podem também apresentar apatia, por exemplo; sendo este sintoma comum as duas condições clínicas ${ }^{(32)}$.

Os pacientes com a forma MND também relataram uma menor presença do suporte social emocional. Com isso, estes pacientes tenderam a se perceber com menor apoio da sua rede de contato diante da sua condição soropositiva. Esses resultados são importantes, pois além da realização de atividades físicas regulares, o estímulo contínuo de atividades cerebrais, por meio de interações sociais e atividades intelectuais, são algumas maneiras para se tentar evitar a perda cognitiva ${ }^{(26,34,35,49)}$.

Dentro das funções cognitivas, os domínios neurocognitivos que se destacaram como comprometidos, usando o critério de Frascati(21) como parâmetro para classificação, foram: memória e atenção. Segundo este critério, as desordens neurocognitivas associadas ao HIV (HAND) são definidas quando o paciente apresenta pelo menos um desvio padrão abaixo da média nos testes neuropsicológicos, comparados às normativas obtidas a partir de uma população controle que corresponde à população alvo em pelo menos idade e educação ${ }^{(3,21)}$. Sendo assim, vale ressaltar que todos os instrumentos utilizados neste estudo foram previamente validados para a população brasileira.

Com relação à memória, houve diferença entre os grupos na análise Post Hoc para com os pacientes com a forma MND. Dentre os tipos avaliados teve destaque o prejuízo na Memória Imediata, que possibilita avaliar a curva de aprendizagem do paciente e na Memória Tardia, que avalia a perda de material verbal previamente aprendido. Com relação a atenção, o maior prejuízo foi na Atenção Alternada que se refere a habilidade em modificar o foco em duas atividades simultâneas.

Os resultados da avaliação neuropsicológica corroboraram os resultados obtidos nos dois questionários de autorrelato (Questionário Neurocognitivo Breve e a Escala de Lawton), pois todos esses instrumentos atuam, dentre outras funções, na identificação dos princípios básicos relacionados ao processo de aprendizagem e retenção de novas 
informações, na capacidade do sujeito em resistir a situações que o distraiam e na flexibilidade mental, sendo estes processos intimamente relacionados à capacidade de auto gerenciamento e independência em sua rotina diária.

A análise neuropsicológica mostrou que o perfil cognitivo do grupo de pacientes sem alterações foi muito parecido com os pacientes ANI. Isso pode ser explicado devido existir ainda controvérsias sobre essa categoria de HAND, enquanto alguns autores mostraram que indivíduos com ANI poderiam desenvolver formas mais graves de comprometimento, outros sublinharam que a definição de ANI não é rigorosa e que a taxa de falso positivo é alta ${ }^{(28)}$. No entanto, independentemente das diferentes opiniões, a forma de HAND sem repercussão funcional na vida diária (comprometimento neurocognitivo assintomático) ainda é o subtipo mais frequente observado ${ }^{(5,22,24,28)}$.

Com relação ao presente estudo, a quantidade de pacientes com a forma leve de alteração neurocognitiva (MND) chama muito a atenção, sendo próxima da porcentagem dos pacientes com a forma ANI. Este resultado é bastante significativo diante de uma população assídua ao tratamento e com quase nenhuma complicação do vírus. E mesmo com este alerta para a presença da forma MND, os resultados do estudo refletem o cenário nacional e internacional mostrando a alta prevalência das alterações cognitivas associadas ao HIV, alertando os profissionais de saúde para a importância de identificação e de diagnóstico e acompanhamento adequado destes pacientes.

O estudo apresenta algumas limitações como, por exemplo, o tamanho da amostra, o que pressupõe que o aumento do número de pacientes reforce os resultados encontrados e até mostre novas associações ainda não encontradas. Sendo que a maior dificuldade na captação dos participantes está na recusa destes em participar. Vale ressaltar que a equipe de neuropsicologia do ambulatório ADEE3002 irá dar continuidade na captação de pacientes para a avaliação neuropsicológica, pois o intuito da equipe é tornar a avaliação neuropsicológica como parte dos exames anuais dos pacientes, não sendo limitada apenas a este projeto.

Não foi possível a realização de exame de neuroimagem, que será solicitado pela equipe médica; porém, as infecções oportunistas do SNC foram rigorosamente avaliadas pela história detalhada do paciente. Apesar dessa limitação, os resultados são confiáveis devido ao fato de terem sido controlados os efeitos de confusão de fatores sociodemográficos como idade, gênero e educação, bem com os confundidores para o diagnóstico de HAND, como, depressão maior e coinfecção.

Com relação aos diferenciais deste estudo tem-se a utilização de uma bateria de avaliação neuropsicológica mais complexa comparada com a maioria dos estudos disponíveis, pois além do teste de rastreio cognitivo (IHDS) utilizamos instrumentos 
neuropsicológicos que possibilitaram uma abrangência maior em relação a quantidade de funções cognitivas superiores avaliados, possibilitando, portanto, maior precisão na detecção das alterações cognitivas. Geralmente os estudos utilizam a bateria de rastreio e em média três ou quatros instrumentos neuropsicológicos ${ }^{(47,50,51,54)}$. Entretanto, no presente estudo foram utilizados sete instrumentos neuropsicológicos além do IHDS, aumentando o rigor da avaliação.

Vale ressaltar o perfil da coorte do ambulatório ADEE3002, devido ao fato que a maioria dos pacientes foram encaminhados pelo Banco de Sangue da Instituição, não sendo admitido nenhum paciente encaminhado de outros serviços de saúde. Deste modo, esses indivíduos apresentarem alto grau de adesão ao tratamento, prevalência de carga viral indetectável e quase inexistência de doenças oportunistas no ato de confirmação do diagnóstico de HIV, tais características tornam essa amostra bastante específica e diferenciada com relação à maioria das coortes do país. 


\section{Conclusão}

O estudo proporcionou as seguintes conclusões:

1) Foi encontrado uma alta prevalência de HAND (60\%), sendo 18 participantes $(33,33 \%)$ com ANI e 14 participantes (25,92\%) com MND, não havendo nenhum resultado de demência na amostra analisada.

2) Mesmo não havendo associação estatística, foi possível observar que os pacientes com a forma leve de alteração neurocognitiva (MND) apresentaram maior tendência em ter sintomas de depressão do que os pacientes com a forma assintomática e com as funções cognitivas preservadas.

3) Mesmo não havendo expressão estatística, foi possível observar que os pacientes com a forma leve de alteração neurocognitiva (MND) apresentaram menor presença do suporte social emocional do que os pacientes com a forma assintomática e com as funções cognitivas preservadas.

4) Não houve diferença na prevalência da adesão ao medicamento antirretroviral, bem como não houve associação estatística entre adesão e HAND, visto que a coorte estudada apresentou alto grau de adesão praticamente em sua totalidade. 
12. Anexos

\section{Anexo I}

IDENTIFICAÇÃO:

DATA: I

\section{DADOS DEMOGRÁFICOS E CLÍNICOS}

- Identificação do paciente (Nro. Do protocolo).

- Matrícula do HC:

- Sexo: (M) (F)

- Idade (anos):

- Orientação sexual:

- Naturalidade:

-Procedência:

-Lateralidade (Preferência manual):

- Escolaridade:

- Ocupação:

- Renda Mensal:

- Problemas visual? ( ) Sim ( ) Não Qual?

- Este problema foi corrigido? ( ) Sim ( ) Não

- Problemas auditivos? ( ) Sim ( ) Não Qual?

- Este problema foi corrigido? ( ) Sim ( ) Não

- Doenças sistêmicas / metabólicas prévias ou atuais (especificar):

- Doenças neuropsiquiátricas prévias ou atuais (especificar):

- Data do diagnóstico de infecção pelo HIV:

- Mecanismo de transmissão da infecção pelo HIV:

- Doença definidora de AIDS:

- Doenças oportunistas prévias:

- CD4+:

- Última contagem de células CD4+ (data): Carga Viral:

- Esquema antirretroviral atual:

- Outros medicamentos:

- Presença de infecção pelo vírus da hepatite B ou C: 
Anexo II

\section{ASSIST - Questionário para Triagem do Uso de Álcool, Tabaco e Outras Substâncias}

Esta avaliação consiste em 8 questões. Depois de ler cuidadosamente cada grupo de idéias, faça um círculo em torno do número $(0,1,2,3,4)$ que melhor descreva sua realidade em relação ao uso de drogas psicoativas. Tome cuidado de ler todas as afirmações, em cada questão, antes de fazer a sua escolha.

Nome: Registro:

Entrevistador: Data: / /

\begin{tabular}{|l|c|c|}
\hline $\begin{array}{l}\text { 1. Na sua vida qual(is) substância(s) você já usou (somente uso não } \\
\text { prescrito pelo médico) }\end{array}$ & NÃO & SIM \\
\hline a.derivados do tabaco & 0 & 3 \\
\hline b. bebidas alcoólicas & 0 & 3 \\
\hline c. maconha & 0 & 3 \\
\hline d. cocaína, crack & 0 & 3 \\
\hline e. anfetaminas ou êxtase & 0 & 3 \\
\hline f. inalantes & 0 & 3 \\
\hline g. hipnóticos/sedativos & 0 & 3 \\
\hline h. alucinógenos & 0 & 3 \\
\hline i. opioides & 0 & 3 \\
\hline j. outras, especificar & 0 & 3 \\
\hline
\end{tabular}

- Se "NÃO" em todos os itens investigue: Nem mesmo quando estava na escola?

- Se "NÃO" em todos os itens, pare a entrevista

- Se "SIM" para alguma droga, continue com as demais questões

\begin{tabular}{|l|l|l|l|l|l|}
\hline $\begin{array}{l}\text { 2. Durante os três últimos } \\
\text { meses, com que freqüência }\end{array}$ & nunca & $\begin{array}{l}1 \text { ou 2 } \\
\text { vezes }\end{array}$ & Mensal & Semanal & $\begin{array}{l}\text { Diário } \\
\text { ou } \\
\text { quase } \\
\text { você utilizou essa(s) } \\
\text { substância(s) que mencionou? } \\
\text { (primeira droga, depois a } \\
\text { segunda droga, etc) }\end{array}$ \\
\hline
\end{tabular}




\begin{tabular}{|l|c|c|c|c|c|}
\hline a.derivados do tabaco & 0 & 2 & 3 & 4 & 5 \\
\hline b. bebidas alcóolicas & 0 & 2 & 3 & 4 & 5 \\
\hline c. maconha & 0 & 2 & 3 & 4 & 5 \\
\hline d. cocaína, crack & 0 & 2 & 3 & 4 & 5 \\
\hline e. anfetaminas ou êxtase & 0 & 2 & 3 & 4 & 5 \\
\hline f. inalantes & 0 & 2 & 3 & 4 & 5 \\
\hline g. hipnóticos/sedativos & 0 & 2 & 3 & 4 & 5 \\
\hline h. alucinógenos & 0 & 2 & 3 & 4 & 5 \\
\hline i. opióides & 0 & 2 & 3 & 4 & 5 \\
\hline j. outras, especificar & 0 & 2 & 3 & 4 & 5 \\
\hline
\end{tabular}

Se "NUNCA" em todos os itens da questão 2 pule para a questão 6, com outras respostas continue com as demais questões

\begin{tabular}{|l|c|c|c|c|c|}
\hline $\begin{array}{l}\text { 3. Durante os três últimos } \\
\text { meses, com que frequência } \\
\text { você teve um forte desejo ou } \\
\text { urgência de consumir? } \\
\text { (primeira droga, depois a } \\
\text { segunda droga, etc) }\end{array}$ & $\begin{array}{l}1 \text { ou 2 } \\
\text { vezes }\end{array}$ & Mensal & Semanal & $\begin{array}{l}\text { Diário } \\
\text { ou } \\
\text { quase } \\
\text { todos } \\
\text { os dias }\end{array}$ \\
\hline a.derivados do tabaco & 0 & 2 & 3 & 4 & 5 \\
\hline b. bebidas alcóolicas & 0 & 2 & 3 & 4 & 5 \\
\hline c. maconha & 0 & 2 & 3 & 4 & 5 \\
\hline d. cocaína, crack & 0 & 2 & 3 & 4 & 5 \\
\hline e. anfetaminas ou êxtase & 0 & 2 & 3 & 4 & 5 \\
\hline f. inalantes & 0 & 2 & 3 & 4 & 5 \\
\hline g. hipnóticos/sedativos & 0 & 2 & 3 & 4 & 5 \\
\hline h. alucinógenos & 0 & 2 & 3 & 4 & 5 \\
\hline i. opióides & 0 & 2 & 3 & 4 & 5 \\
\hline j. outras, especificar & 0 & 2 & 3 & 4 & 5 \\
\hline
\end{tabular}

\begin{tabular}{|r|l|l|l|l|l|}
\hline 4. Durante os três últimos & nunca & $\begin{array}{l}1 \text { ou } 2 \\
\text { vezes }\end{array}$ & Mensal & Semanal & $\begin{array}{l}\text { Diário } \\
\text { ou } \\
\text { quase } \\
\text { todos com que frequência o } \\
\text { os dias }\end{array}$ \\
$\begin{array}{r}\text { droga, depois a segunda droga, } \\
\text { etc) resultou em problema de }\end{array}$ & & & & & \\
\hline
\end{tabular}




\begin{tabular}{|l|c|c|c|c|c|}
\hline $\begin{array}{l}\text { saúde, social, legal ou } \\
\text { financeiro? }\end{array}$ & & & & & \\
\hline a.derivados do tabaco & 0 & 2 & 3 & 4 & 5 \\
\hline b. bebidas alcóolicas & 0 & 2 & 3 & 4 & 5 \\
\hline c. maconha & 0 & 2 & 3 & 4 & 5 \\
\hline d. cocaína, crack & 0 & 2 & 3 & 4 & 5 \\
\hline e. anfetaminas ou êxtase & 0 & 2 & 3 & 4 & 5 \\
\hline f. inalantes & 0 & 2 & 3 & 4 & 5 \\
\hline g. hipnóticos/sedativos & 0 & 2 & 3 & 4 & 5 \\
\hline h. alucinógenos & 0 & 2 & 3 & 4 & 5 \\
\hline i. opióides & 0 & 2 & 3 & 4 & 5 \\
\hline j. outras, especificar & 0 & 2 & 3 & 4 & 5 \\
\hline
\end{tabular}

\begin{tabular}{|l|c|c|c|c|c|}
\hline $\begin{array}{l}\text { 5. Durante os três últimos } \\
\text { meses, com que frequência por } \\
\text { causa do seu uso (primeira } \\
\text { droga, depois a segunda droga, } \\
\text { etc) você deixou de fazer coisas } \\
\text { que eram normalmente } \\
\text { esperadas de você? }\end{array}$ & $\begin{array}{l}\text { 1 ou 2 } \\
\text { vezes }\end{array}$ & Mensal & Semanal & $\begin{array}{l}\text { Diário } \\
\text { ou } \\
\text { quase } \\
\text { todos } \\
\text { os dias }\end{array}$ \\
\hline a.derivados do tabaco & 0 & 2 & 3 & 4 & 5 \\
\hline b.bebidas alcóolicas & 0 & 2 & 3 & 4 & 5 \\
\hline c. maconha & 0 & 2 & 3 & 4 & 5 \\
\hline d. cocaína, crack & 0 & 2 & 3 & 4 & 5 \\
\hline e. anfetaminas ou êxtase & 0 & 2 & 3 & 4 & 5 \\
\hline f. inalantes & 0 & 2 & 3 & 4 & 5 \\
\hline g. hipnóticos/sedativos & 0 & 2 & 3 & 4 & 5 \\
\hline h. alucinógenos & 0 & 2 & 3 & 4 & 5 \\
\hline i. opióides & 0 & 2 & 3 & 4 & 5 \\
\hline j. outras, especificar & 0 & 2 & 3 & 4 & 5 \\
\hline
\end{tabular}

FAÇA as questões 6 e 7 para todas as substâncias mencionadas na questão 1

\begin{tabular}{|l|l|l|l|l|l|}
\hline $\begin{array}{l}\text { 6. Há amigos, parentes ou outra } \\
\text { pessoa que tenha demonstrado } \\
\text { preocupação com o uso de }\end{array}$ & $\begin{array}{l}1 \text { ou 2 } \\
\text { vezes }\end{array}$ & Mensal & Semanal & $\begin{array}{l}\text { Diário } \\
\text { ou } \\
\text { quase }\end{array}$ \\
\hline
\end{tabular}




\begin{tabular}{|l|c|c|c|c|c|}
\hline $\begin{array}{l}\text { (primeira droga, depois a } \\
\text { segunda droga, etc)? }\end{array}$ & & & & & $\begin{array}{l}\text { todos } \\
\text { os dias }\end{array}$ \\
\hline a.derivados do tabaco & 0 & 2 & 3 & 4 & 5 \\
\hline b.bebidas alcóolicas & 0 & 2 & 3 & 4 & 5 \\
\hline c. maconha & 0 & 2 & 3 & 4 & 5 \\
\hline d. cocaína, crack & 0 & 2 & 3 & 4 & 5 \\
\hline e. anfetaminas ou êxtase & 0 & 2 & 3 & 4 & 5 \\
\hline f. inalantes & 0 & 2 & 3 & 4 & 5 \\
\hline g. hipnóticos/sedativos & 0 & 2 & 3 & 4 & 5 \\
\hline h. alucinógenos & 0 & 2 & 3 & 4 & 5 \\
\hline i. opióides & 0 & 2 & 3 & 4 & 5 \\
\hline j. outras, especificar & 0 & 2 & 3 & 4 & 5 \\
\hline
\end{tabular}

\begin{tabular}{|l|c|c|c|c|c|}
\hline $\begin{array}{l}\text { 7. Alguma vez você já tentou } \\
\text { controlar, diminuir ou parar o } \\
\text { uso de (primeira droga, depois } \\
\text { a segunda droga, etc) e não } \\
\text { conseguiu? }\end{array}$ & $\begin{array}{l}\text { N ou 2 } \\
\text { vezes }\end{array}$ & Mensal & Semanal & $\begin{array}{l}\text { Diário } \\
\text { ou } \\
\text { quase } \\
\text { todos } \\
\text { os dias }\end{array}$ \\
\hline a.derivados do tabaco & 0 & 2 & 3 & 4 & 5 \\
\hline b.bebidas alcóolicas & 0 & 2 & 3 & 4 & 5 \\
\hline c. maconha & 0 & 2 & 3 & 4 & 5 \\
\hline d. cocaína, crack & 0 & 2 & 3 & 4 & 5 \\
\hline e. anfetaminas ou êxtase & 0 & 2 & 3 & 4 & 5 \\
\hline f. inalantes & 0 & 2 & 3 & 4 & 5 \\
\hline g. hipnóticos/sedativos & 0 & 2 & 3 & 4 & 5 \\
\hline h. alucinógenos & 0 & 2 & 3 & 4 & 5 \\
\hline i. opióides & 0 & 2 & 3 & 4 & 5 \\
\hline j. outras, especificar & 0 & 2 & 3 & 4 & 5 \\
\hline
\end{tabular}

Nota Importante: Pacientes que tenham usado drogas injetáveis nos últimos 3 meses devem ser perguntados sobre seu padrão de uso injetável durante este período, para determinar seus níveis de risco e a melhor forma de intervenção. 


\begin{tabular}{|l|l|lr|l|}
\hline $\begin{array}{l}\text { 8. Alguma vez já usou drogas por } \\
\text { injeção? (Apenas uso não médico) }\end{array}$ & $\begin{array}{l}\text { NÂO, } \\
\text { nunca }\end{array}$ & $\begin{array}{l}\text { SIM, } \\
\text { últimos } \\
\text { meses }\end{array}$ & 3 & $\begin{array}{l}\text { SIM, mas não } \\
\text { últimos 3 meses }\end{array}$ \\
\hline
\end{tabular}

PONTUAÇÃO PARA CADA DROGA

\begin{tabular}{|l|l|l|l|l|}
\hline & $\begin{array}{l}\text { Anote a } \\
\text { pontuação cada } \\
\text { para somE } \\
\text { droga. Somuma } \\
\text { SomENTE das } \\
\text { questões } \\
2,3,4,5,6 \text { e 7 }\end{array}$ & $\begin{array}{l}\text { Intervenção } \\
\text { intervenção } \\
\text { breve }\end{array}$ & $\begin{array}{l}\text { Encaminhar } \\
\text { para } \\
\text { tratamento } \\
\text { mais } \\
\text { intensivo }\end{array}$ \\
\hline Tabaco & & $0-3$ & $4-26$ & 27 ou mais \\
\hline Alcool & & $0-3$ & $11-26$ & 27 ou mais \\
\hline Maconha & & $0-3$ & $4-26$ & 27 ou mais \\
\hline Cocaína & & $0-3$ & $4-26$ & 27 ou mais \\
\hline Anfetaminas & & $0-3$ & $4-26$ & 27 ou mais \\
\hline Inalantes & & $0-3$ & $4-26$ & 27 ou mais \\
\hline Hipnóticos/sedativos & & $0-3$ & $4-26$ & 27 ou mais \\
\hline Alucinógenos & & $0-3$ & $4-26$ & 27 ou mais \\
\hline Opiódes & & $0-3$ & $4-26$ & 27 ou mais \\
\hline
\end{tabular}




\section{Anexo III}

\section{OUESTIONÁRIO NEUROCOGNITIVO BREVE}

1. Memória: Você tem perda de memória frequente? Se esquece de eventos especiais ou reuniões, inclusive aquelas mais recentes?":

(sim, definitivamente) (sim, às vezes) (não)

2. Lentificação psicomotora: Você sente que você está mais lento quando pensa, planeja atividades ou resolve problemas?":

(sim, definitivamente) (sim, às vezes) (não)

3. Atenção: Você tem dificuldades para prestar atenção durante uma conversa, ler um jornal ou assistir um filme?

(sim, definitivamente) (sim, às vezes) (não) 


\section{Anexo IV}

\section{International HIV Dementia Scale. Adaptado de: Sackor e colaboradores, 2005.}

1. Registro de memória: Mencionar 4 palavras que o paciente deverá recordar (cão, chapéu, feijão, vermelho).

Apresentar cada palavra em 1 segundo. Depois, peça para o paciente repetir as 4 palavras que você acabou de mencionar.

Repita as palavras que o paciente não lembrou imediatamente.

Explique ao paciente que você perguntará por essas palavras alguns minutos depois.

2. Rapidez motora: Solicite que o paciente bata os dois primeiros dedos da mão não dominante tão ampla e rapidamente como seja possível. Pontuação:

$4=15$ em 5 segundos

$3=11-14$ em 5 segundos

$2=7-10$ em 5 segundos

$1=3-6$ em 5 segundos

$0=0-2$ em 5 segundos

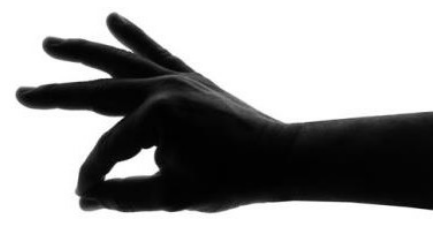

3. Rapidez psicomotora: O paciente deverá realizar os seguintes movimentos com a mão não dominante tão rápido como seja possível: 1) Apertar a mão em punho sobre uma superfície plana, 2) Colocar a mão sobre uma superfície plana com a palma para baixo, e 3) Colocar a mão perpendicular à superfície plana sobre o lado do quinto dedo. Demonstrar e solicitar que o paciente pratique duas vezes esses movimentos.

Pontuação:

$4=4$ sequências em 10 segundos

$3=3$ sequências em 10 segundos

2 = 2 sequências em 10 segundos

$1=1$ sequência em 10 segundos

$0=$ incapaz de realizar
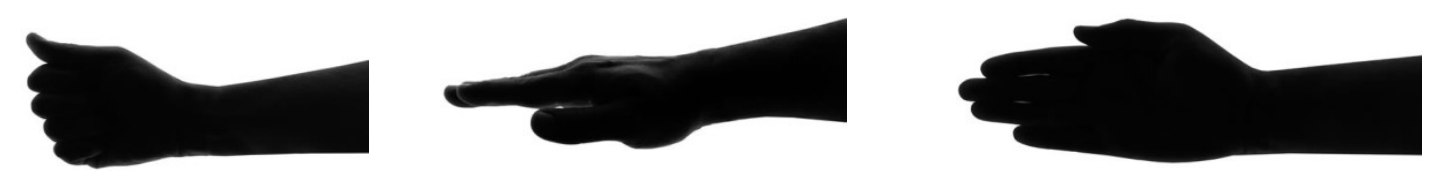

4. Memória: perguntar ao paciente pelas 4 palavras mencionadas ao início desta parte da avaliação. Para as palavras não recordadas, mencionar uma clave semântica, por exemplo: animal (cão), peça de roupa (chapéu), alimento (feijão), cor (vermelho). Dar 1 ponto para cada palavra lembrada espontaneamente. Dar 0.5 ponto para cada palavra lembrada após a clave semântica. Máximo = 4 pontos

\section{Pontuação Total:}

Interpretação da International HIV Dementia Scale: O escore final consiste na somatória dos itens 1-3. O máximo escore possível é de 12 pontos. Pacientes com pontuações menores ou iguais a 10 devem ser considerados para investigação de HAND. 


\section{Anexo V}

\section{Escala de Atividade de Vida Diária Lawton}

[A] Em relação ao uso de telefone:

3 = recebe e faz ligações sem assistência

2 = necessita de assistência para realizar ligações telefônicas

1 = não tem o hábito ou é incapaz de usar o telefone

[B] Em relação às viagens:

3 = realiza viagens sozinho

2 =somente viaja quando tem companhia

1 = não tem o hábito ou é incapaz de usar de viajar

[C] Em relação à realização de compras:

$3=$ realiza compras quando é fornecido transporte

2 = somente faz compras quando tem companhia

1 = não tem o hábito ou é incapaz de realizar compras

[D] Em relação ao preparo de refeições

3 = planeja e cozinha as refeições completas

2 = prepara somente refeições pequenas ou quando tem ajuda

1 = não tem o hábito ou é incapaz de preparar refeições

[E] Em relação ao trabalho doméstico

$3=$ realiza tarefas pesadas

2 = realiza tarefas leves, precisando de ajuda nas pesadas

1 = não tem o hábito ou é incapaz de realizar trabalhos domésticos

[F] Em relação ao uso de medicamentos

3 = faz uso de medicamentos sem assistência

2 = necessita de lembretes ou de assistência

1 = é incapaz de controlar sozinho o uso de medicamentos

[G] Em relação ao manuseio de dinheiro

3 = paga contas sem auxilio

2 = necessita de assistência para o pagar contas

1 = não tem o hábito de lidar com dinheiro ou é incapaz de manusear dinheiro, contas 
Anexo VI

ESCALA HAD

ZIGMOND, A.S. \& SNAITH R.P. THE HOSPITAL AXIETY AND DEPRESSION SCALE. ACTA PSYCH SCAND, 67:361-70,1983

Nome:

Data:

Idade:

Marque a resposta que melhor corresponder a como você tem se sentido na última semana.

Eu me sinto tenso ou contraido:

( ) A maior parte do tempo

( ) Boa parte do tempo

( ) De vez em quando

( ) Nunca

Ainda gosto de muitas coisas de antes:

( ) Sim, do mesmo jeito que antes

( ) Não tanto quanto antes

( ) Só um pouco

( ) Já não sinto mais prazer em nada

A Eu sinto uma espécie de medo, como se alguma coisa ruim fosse acontecer:

( ) Sim, e de um jeito muito forte

( ) $\mathrm{Sim}$, mas não tão forte

( ) Um pouco, mas isso não me preocupa

( ) Não sinto nada disso

D Dou risada e me divirto quando vejo coisas engraçadas:

( ) Do mesmo jeito que antes

( ) Atualmente um pouco menos

( ) Atualmente bem menos

( ) Não consigo mais

Estou com a cabeça cheia de preocupações:

( ) A maior parte do tempo

( ) Boa parte do tempo

( ) De vez em quando

( ) Raramente

Eu me sinto alegre:

( ) Nunca

( ) Poucas vezes

( ) Muitas vezes

( ) A maior parte do tempo

Consigo ficar à vontade e me sentir relaxado:

( ) $\mathrm{Sim}$, quase sempre

( ) Muitas vezes

( ) Poucas vezes

( ) Nunca

Eu estou lento para pensar e fazer coisas:
Quase sempre
( ) Muitas vezes
( ) De vez em quando
( ) Nunca

A Eu tenho uma sensação ruim ou de medo, como um frio na barriga ou um aperto no estômago:

( ) Nunca

( ) De vez em quando

( ) Muitas vezes

( ) Quase sempre

D Eu perdi o interesse de cuidar de minha aparência:

( ) Completamente

( ) Não estou mais me cuidando como eu deveria

( ) Talvez não tanto quanto antes

( ) Me cuido do mesmo jeito que antes

A

Eu sinto inquieto, como se eu não pudesse ficar parado em lugar nenhum:

( ) $\mathrm{Sim}$, demais

( ) Bastante

( ) Um pouco

( ) Não me sinto assim

D Fico esperando animado as coisas boas que estào por vir:

( ) Do mesmo jeito que antes

( ) Um pouco menos do que antes

( ) Bem menos do que antes

( ) Quase nunca

De repente, tenho a sensação de entrar em pânico:

( ) A quase todo momento

( ) Várias vezes

( ) De vez em quando

( ) Não sinto isso

D Consigo sentir prazer quando assisto um bom programa de televisão, de rádio, ou quando leio alguma coisa

( ) Quase sempre

( ) Várias vezes

( ) Poucas vezes

( ) Quase nunca

TOTAL A: TOTAL D:

Ponto de corte $A: 8$

Ponto de corte D: 9 
Anexo VII

\section{Escala para Avaliacão do Suporte social em HIVIAids. Adaptado de: Seidl e} Tróccoli, 2006.

Este formulário é sobre o apoio ou a ajuda que você tem recebido de diferentes pessoas com quem você se relaciona. Por favor, informe a frequência dos diferentes tipos de apoio que tem recebido em função de ser portador do vírus HIV e estar com AIDS e a sua satisfação em relação a cada um deles marcando com um $X$ a resposta que considerar mais adequada. Pedimos que não deixe nenhuma questão em branco. Mais uma vez, obrigada pela sua colaboração.

1. Você tem recebido apoio em situações concretas, facilitando a realização do seu tratamento de saúde? (Exemplo: tomar conta dos filhos quando você tem consulta, cuidar da casa nos dias de consulta ou qualquer outra situação).

1. Nunca;

2. Raramente;

3. Às vezes;

4. Frequentemente;

5. Sempre.

1.1. Quão satisfeito (a) você está em relação a esse apoio que tem recebido?

1. Muito insatisfeito (a);

2. Insatisfeito (a);

3. Nem satisfeito (a) Nem insatisfeito (a);

4. Satisfeito (a);

5. Muito satisfeito (a).

2. Você tem recebido apoio em questões financeiras, como divisão das despesas na casa, dinheiro dado ou emprestado?

1. Nunca;

2. Raramente;

3. Às vezes;

4. Frequentemente;

5. Sempre.

2.1 Quão satisfeito (a) você está em relação a esse apoio recebido?

1. Muito insatisfeito (a);

2. Insatisfeito (a);

3. Nem satisfeito (a) Nem insatisfeito (a);

4. Satisfeito (a);

5. Muito satisfeito (a).

3. Você tem recebido apoio em atividades práticas do seu dia a dia? (Exemplo: arrumação da casa, ajuda no cuidado dos filhos, preparo de refeições ou qualquer outra coisa)

1. Nunca;

2. Raramente;

3. Às vezes;

4. Frequentemente;

5. Sempre.

3.1 Quão satisfeito (a) você está em relação a esse apoio recebido?

1. Muito Insatisfeito (a);

2. Insatisfeito (a);

3. Nem satisfeito (a) Nem insatisfeito (a);

4. Satisfeito (a);

5. Muito satisfeito (a). 
4. Você tem recebido apoio em relação ao seu próprio cuidado de saúde? (Exemplo: lembrar a hora de tomar um medicamento ou o dia de fazer um exame, comprar um remédio para você, acompanhar em uma consulta, ou qualquer outra situação)

1. Nunca;

2. Raramente;

3. Às vezes;

4. Frequentemente;

5. Sempre.

4.1 Quão satisfeito (a) você está em relação a esse apoio recebido?

1. Muito Insatisfeito (a);

2. Insatisfeito (a);

3. $\quad$ Nem satisfeito (a) Nem insatisfeito (a);

4. Satisfeito (a);

5. $\quad$ Muito satisfeito (a)

5. Você tem recebido apoio de pessoa(s) com quem você pode contar em caso de necessidade? (financeira, alimentação e tratamento)

1. Nunca;

2. Raramente;

3. Às vezes;

4. Frequentemente;

5. Sempre.

5.1 Quão satisfeito (a) você está em relação a esse apoio recebido?

1. Muito Insatisfeito (a);

2. Insatisfeito (a);

3. $\quad$ Nem satisfeito (a) Nem insatisfeito (a);

4. $\quad$ Satisfeito (a);

5. Muito satisfeito (a).

6. Você tem recebido apoio de pessoas que lhe dão coisas que você precisa em seu dia a dia?

1. Nunca;

2. Raramente;

3. Às vezes;

4. Frequentemente;

5. Sempre.

6.1. Quão satisfeito (a) você está em relação ao apoio de pessoas que lhe dão coisas que você precisa em seu dia a dia?

1. Muito Insatisfeito (a);

2. Insatisfeito (a);

3. Nem satisfeito (a) Nem insatisfeito (a);

4. $\quad$ Satisfeito (a);

5. $\quad$ Muito satisfeito (a).

Com base nos tipos de apoio mencionados acima (questões de 1 a 5), marque na lista abaixo com um $X$ a(s) pessoa(s) que têm dado este tipo de apoio a você:

( ) esposo(a), companheiro(a) ou namorado(a).

( ) pessoa(s) da família que mora(m) comigo. Quem?

( ) pessoa(s) da família que não mora(m) comigo. Quem?

() amigo(s).

( ) chefe ou colega(s) de trabalho.

() vizinho(s).

( ) profissionais de saúde.

( ) Outra pessoa. Quem?

7. Você tem recebido apoio que faz você se sentir valorizado(a) como pessoa?

1. Nunca; 
2. Raramente;

3. Às vezes;

4. Frequentemente;

5. Sempre.

7.1 Quão satisfeito (a) você está em relação a esse apoio recebido?

1. Muito Insatisfeito (a);

2. Insatisfeito (a);

3. Nem satisfeito (a) Nem insatisfeito (a);

4. Satisfeito (a);

5. Muito satisfeito (a).

8. Você tem recebido apoio de alguém com que possa desabafar conversar sobre assuntos relacionados à sua enfermidade?

1. Nunca;

2. Raramente;

3. Às vezes;

4. Frequentemente;

5. Sempre.

8.1 Quão satisfeito (a) você está em relação a esse apoio recebido?

1. Muito Insatisfeito (a);

2. Insatisfeito (a);

3. Nem satisfeito (a) Nem insatisfeito (a);

4. Satisfeito (a);

5. Muito satisfeito (a).

9. Você tem recebido apoio de alguém que lhe fornece informações, melhorando o seu nível de conhecimento sobre o seu problema da saúde (fazendo compreender o seu problema)?

1. Nunca;

2. Raramente;

3. Às vezes;

4. Frequentemente;

5. Sempre.

9.1 Quão satisfeito (a) você está em relação a esse apoio recebido?

1. Muito Insatisfeito (a);

2. Insatisfeito (a);

3. Nem satisfeito (a) Nem insatisfeito (a);

4. Satisfeito (a);

5. Muito satisfeito (a).

10. Você tem recebido apoio de alguém que faz você se sentir parte de sua família, da vizinhança, do trabalho?

1. Nunca;

2. Raramente;

3. Às vezes;

4. Frequentemente;

5. Sempre.

10.1 Quão satisfeito (a) você está em relação a esse apoio recebido?

1. Muito Insatisfeito (a);

2. Insatisfeito (a);

3. Nem satisfeito (a) Nem insatisfeito (a);

4. Satisfeito (a);

5. Muito satisfeito (a).

11. Você tem recebido apoio que Ihe ajuda a melhorar o seu humor, estado de espírito, estado emocional?

1. Nunca;

2. Raramente; 
3. Às vezes;

4. Frequentemente;

5. Sempre.

11.1 Quão satisfeito (a) você está em relação a esse apoio recebido?

1. Muito Insatisfeito (a);

2. Insatisfeito (a);

3. Nem satisfeito (a) Nem insatisfeito (a);

4. Satisfeito (a);

5. Muito satisfeito (a).

12. Você tem recebido apoio quando precisa de companhia para se divertir ou fazer atividades de lazer?

1. Nunca;

2. Raramente;

3. Às vezes;

4. Frequentemente;

5. Sempre.

12.1 Quão satisfeito (a) você está em relação a esse apoio recebido?

1. Muito Insatisfeito (a);

2. Insatisfeito (a);

3. $\quad$ Nem satisfeito (a) Nem insatisfeito (a);

4. Satisfeito (a);

5. $\quad$ Muito satisfeito (a).

Com base nos tipos de apoio mencionados acima (questões de 6 a 12), marque na lista abaixo com um $X$ a(s) pessoa(s) que tem dado este tipo de apoio a você:

( ) esposo(a), companheiro(a) namorado(a).

( ) pessoa(s) da família que mora(m)comigo. Quem?

( ) pessoa(s) da família que não mora $(\mathrm{m})$ comigo. Quem?

( ) amigo(s).

( ) chefe ou colega(s) de trabalho.

( ) vizinho(s).

( ) profissionais de saúde.

( ) Outra pessoa. Quem? 


\section{Anexo VIII}

Questionário para a Avaliação da Adesão ao Tratamento Antiretroviral (CEAT-VIH, Versão em portuguẻs [Brasil])

Durante a última sernana

1. Deixou de tomar sua medicaçâa alguma vez?

2. Se alguma vez sentiu-se melhor, deixou de tomar sua medicação?

3. Se alguma vez depois de tomar sua medicação sentiu-se pior, deixou de tomá-la?

4. Se alguma vez se sentiu triste ou deprimido,

deixou de tomar sua medicação?

\begin{tabular}{|l|c|l|l|l|}
\hline Sempre & $\begin{array}{c}\text { Mais da metade } \\
\text { das vezes }\end{array}$ & $\begin{array}{c}\text { Aproximadamente } \\
\text { a metade das vezes }\end{array}$ & $\begin{array}{c}\text { Alguma } \\
\text { vez }\end{array}$ & $\begin{array}{c}\text { Nenhuma } \\
\text { vez }\end{array}$ \\
\hline & & & & \\
\hline & & & & \\
\hline & & & & \\
\hline & & & & \\
\hline
\end{tabular}

5. Lembra-se que remédios está tomando nesse momento? (escrever os nomes)

6. Como é a relação que mantém com o seu médico?

\begin{tabular}{|c|c|c|c|c|}
\hline Ruim & Um pouco ruim & Regular & Pode melhorar & Boa \\
\hline
\end{tabular}

7. Quanto você se esforça para seguir com o tratamento?

8. Quanta informação você tem sobre os medicamentos que toma para o HIV?

9. Quanto beneficio pode lhe trazer o uso destes medicamentos?

10. Considera que sua saúde melhorou desde que começou a tomar os medicamentos para o HIV?

11. Até que ponto sente-se capaz de seguir com o tratamento?

\begin{tabular}{|l|l|l|l|l|}
\hline Nada & Pouco & Regular & Bastante & Muito \\
\hline & & & & \\
\hline & & & & \\
\hline & & & & \\
\hline & & & & \\
\hline & & & & \\
\hline
\end{tabular}

12. Normalmente está acostumado a tomar a medicação na hora certa?

13. Quando os resultados dos exames são bons, seu médico costuma utilizá-los para lhe dar ânimo e motivação para seguir com o tratamento?

\begin{tabular}{|c|c|c|c|c|}
\hline $\begin{array}{c}\text { Não, } \\
\text { nunca }\end{array}$ & $\begin{array}{c}\text { Sim, } \\
\text { alguma } \\
\text { vez }\end{array}$ & $\begin{array}{c}\text { Sim, aproximada- } \\
\text { mente a metade } \\
\text { das vezes }\end{array}$ & $\begin{array}{c}\text { Sim, } \\
\text { muitas } \\
\text { vezes }\end{array}$ & $\begin{array}{c}\text { Sim, } \\
\text { sempre }\end{array}$ \\
\hline & & & & \\
\hline & & & & \\
\hline
\end{tabular}

14. Como sente-se em geral com o tratamento desde que começou a tomar seus remédios?

\begin{tabular}{|l|l|l|l|l|}
\hline Muito insatisfeito & Insatisfeito & Indiferente & Satisfeito & Muito satisfeito \\
\hline
\end{tabular}

15. Como avalia a intensidade dos efeitos colaterais relacionados com o uso dos medicamentos para o HIV?

\begin{tabular}{|c|c|c|c|c|}
\hline Muito intensos & Intensos & Medianamente intensos & Pouco intensos & Nada intensos \\
\hline
\end{tabular}

16. Quanto tempo acredita que perde ccupando-se em tomar seus remédios?

\begin{tabular}{|c|c|c|c|c|}
\hline Muito tempo & Bastante tempo & Regular & Pouco tempo & Nada de tempo \\
\hline
\end{tabular}

17. Que avaliação tem de si mesmo com relação a toma dos remédios para o HIV?

\begin{tabular}{|l|c|c|c|c|}
\hline Nada cumpridor & Pouco cumpridor & Regular & Bastante & Muito cumpridor \\
\hline
\end{tabular}

18. Quanta dificuldade tem para tomar a medicação?

\begin{tabular}{|l|l|l|l|l|}
\hline Muita dificuldade & Bastante dificuldade & Regular & Pouca dificuldade & Nenhuma dificuldade \\
\hline
\end{tabular}

19. Desde que está em tratamento alguma vez deixou de tomar sua medicação um dia completo, ou mais de um? [Se responde afirmativamente, Quantos dias aproximadamente?]

20. Utiliza alguma estratégia para lembrar-se de tomar a medicaçāo? Qual?

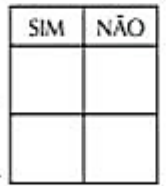




\section{Anexo IX}

\section{Dígitos}

II) REGRA DE INTERRUPCÄO

Digitos ordem Direta e nversa.

Aplicar sempre as 2 tentativas de cada item

(24)

PONTUAÇÃO

Cada tentativa: 0 ou 1 ponto para cada resposta mesmo se acertou a $1^{\circ}$.

ontuação do item: tentativa $1+$ tentativa 2.

\begin{tabular}{|c|c|c|c|c|c|c|c|c|c|c|}
\hline \multicolumn{2}{|c|}{$\begin{array}{l}\text { Dígitos Ordem Direta } \\
\text { Itens / Tentativas / Respostas }\end{array}$} & \multirow[t]{2}{*}{$\begin{array}{c}\text { Pontos } \\
\text { Tentativg } 1 \\
\text { (0 ou 1) }\end{array}$} & \multirow[t]{2}{*}{$\begin{array}{l}\text { Pontos } \\
\text { Itens } \\
0,1 \text { ou } 2\end{array}$} & \multicolumn{5}{|c|}{$\begin{array}{l}\text { Dígitos Ordem Inversa } \\
\text { Itens / Tentatlvas / Respostas }\end{array}$} & \begin{tabular}{|c|} 
Pontos \\
Tentativa 2 \\
$(0$ ou 1$)$
\end{tabular} & \multirow[t]{2}{*}{$\begin{array}{c}\text { Pontos } \\
\text { itens } \\
0,1 \text { ou } 2 \\
\end{array}$} \\
\hline 1. $\frac{1}{2}$ & $\begin{array}{l}1-7 \\
6-3\end{array}$ & & & 1. & \multicolumn{4}{|c|}{\begin{tabular}{l|l}
1 & $2-4$ \\
2 & $5-7$
\end{tabular}} & & \\
\hline 2. $\frac{1}{2}$ & $\frac{5-8-2}{6-9-4}$ & & & 2. & $\frac{1}{2}$ & \multicolumn{3}{|l|}{\begin{tabular}{|l|}
$4-1-5$ \\
$6-2-9$
\end{tabular}} & & \\
\hline 3. $\frac{1}{2}$ & $\begin{array}{l}6-4-3-9 \\
7-2-8-6\end{array}$ & & & 3. & $\frac{1}{2}$ & \multicolumn{3}{|l|}{$3.2-7.9$} & & \\
\hline 4. $\frac{1}{2}$ & $\begin{array}{l}4-2-7-3-1 \\
7-5-8-3-6\end{array}$ & & & 4. & $\frac{1}{2}$ & \multicolumn{3}{|l|}{$\frac{1-5-2-8-6}{6-1-8-4-3}$} & & \\
\hline 5. $\frac{1}{2}$ & $\frac{6-1-9-4-7-3}{3-9-2-4-8-7}$ & & & 5. & $\frac{1}{2}$ & \multicolumn{2}{|l|}{$5-3-9-4-1-8$} & & & \\
\hline 6. $\frac{1}{2}$ & $\frac{5-9-1-7-4-2-8}{4-1-7-9-3-8-6}$ & & & 6. & $\frac{1}{2}$ & \multicolumn{2}{|l|}{$8-1-2-9-3-6-5$} & & & \\
\hline 7. $\frac{1}{2}$ & \begin{tabular}{|l}
$3-8-2-9-5-1-7-4$ \\
$5-8-1-9-2-6-4-7$
\end{tabular} & & & 7. & $\frac{1}{2}$ & \multicolumn{3}{|l|}{$\begin{array}{l}7-2-8-1-9-6-5-3 \\
9-4-3-7-6-2-5-8 \\
\end{array}$} & & \\
\hline 8. $\frac{1}{2}$ & $\begin{array}{l}2-7-5-8-6-2-5-8-4 \\
7-1-3-9-4-2-5-6-8\end{array}$ & & & \multicolumn{6}{|c|}{$\begin{array}{l}\text { Total de Pontos Ordem Inversa } \\
\qquad(\text { Máximo }=14)\end{array}$} & \\
\hline \multicolumn{3}{|c|}{$\begin{array}{l}\text { Total de Pontos Ordem Direta } \\
\qquad(\text { Móximo }=16)\end{array}$} & & & & & Ordem Direta & + & Ordem Inverso $=$ & Móximo $=30$ \\
\hline
\end{tabular}




\section{Anexo X}

\section{RAVLT - Rey Auditory Verbal Learning Test - Protocolo de Registros}

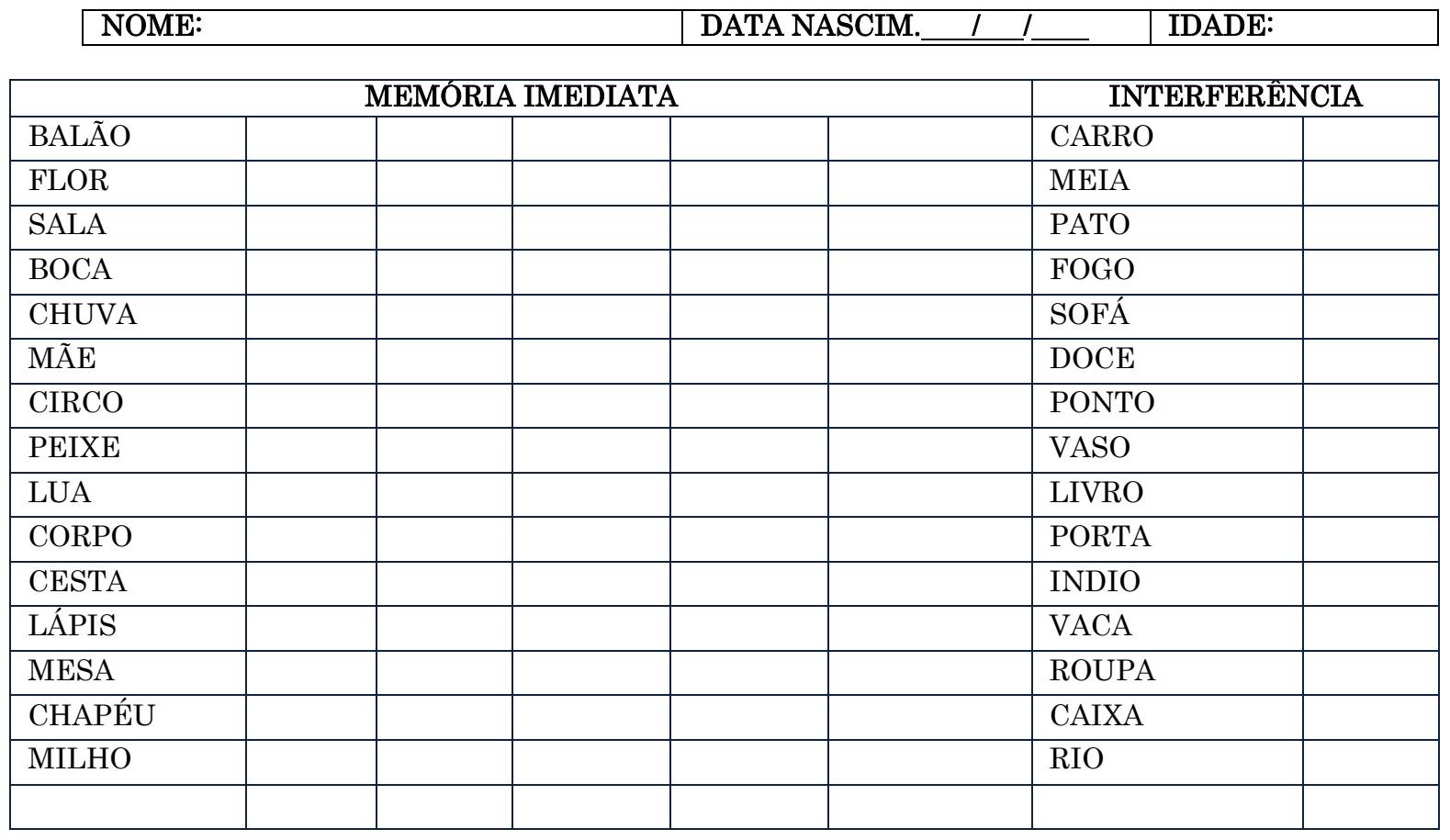

\begin{tabular}{|l|l|l|l|l|l|}
\hline \multicolumn{2}{|c|}{ PÓS INTERF. } & \multicolumn{2}{c|}{ EVOCAÇ̃̃O TARDIA (30") } & \multicolumn{3}{c|}{ RECONHECIMENTO } \\
\hline BALÃO & BALÃO & & LUA & PATO & AULA \\
\hline FLOR & FLOR & & GALO & CESTA & MILHO \\
\hline SALA & SALA & & FOGO & LIVRO & BOLO \\
\hline BOCA & BOCA & & CHAPEU & PONTO & PEIXE \\
\hline CHUVA & CHUVA & & VASO & FLOR & BOTÃO \\
\hline MÃE & MÃE & & LAGO & ISCA & LEITE \\
\hline CIRCO & CIRCO & PORTA & CHUVA & MEIA \\
\hline PEIXE & PEIXE & & DENTE & CAIXA & JARDIM \\
\hline LUA & LUA & & RIO & ROSA & FESTA \\
\hline CORPO & CORPO & INDIO & CIRCO & DOCE \\
\hline CESTA & CESTA & BALÃO & LÁPIS & SOL \\
\hline LÁPIS & LÁPIS & RUA & VACA & PAPEL \\
\hline MESA & MESA & & PLANTA & SALA & MAR \\
\hline CHAPÉU & CHAPÉU & ROUPA & FILHO & VENTO \\
\hline MILHO & MILHO & & CORPO & BOLA & \\
\hline & & & & \\
\hline & & & & & \\
\hline & & & & &
\end{tabular}


Anexo XI

Códigos

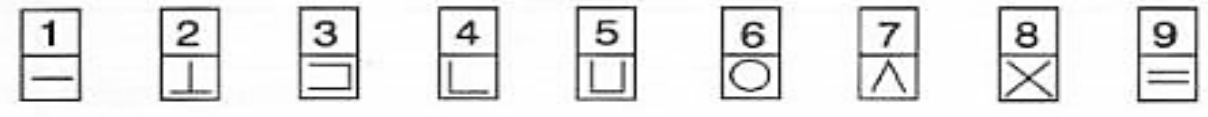

Itens de exemplos

\begin{tabular}{|l|l|l|l|l|l|l|l|l|l|l|l|l|l|l|l|l|l|l|l|}
\hline 2 & 1 & 3 & 7 & 2 & 4 & 8 & 2 & 1 & 3 & 2 & 1 & 4 & 2 & 3 & 5 & 2 & 3 & 1 & 4 \\
\hline & & & & & & & & & & & & & & & & & & & \\
\hline
\end{tabular}

\begin{tabular}{|l|l|l|l|l|l|l|l|l|l|l|l|l|l|l|l|l|l|l|l|}
\hline 5 & 6 & 3 & 1 & 4 & 1 & 5 & 4 & 2 & 7 & 6 & 3 & 5 & 7 & 2 & 8 & 5 & 4 & 6 & 3 \\
\hline & & & & & & & & & & & & & & & & & & & \\
\hline
\end{tabular}

\begin{tabular}{|l|l|l|l|l|l|l|l|l|l|l|l|l|l|l|l|l|l|l|l|}
\hline 7 & 2 & 8 & 1 & 9 & 5 & 8 & 4 & 7 & 3 & 6 & 2 & 5 & 1 & 9 & 2 & 8 & 3 & 7 & 4 \\
\hline & & & & & & & & & & & & & & & & & & & \\
\hline
\end{tabular}

\begin{tabular}{|l|l|l|l|l|l|l|l|l|l|l|l|l|l|l|l|l|l|l|l|}
\hline 6 & 5 & 9 & 4 & 8 & 3 & 7 & 2 & 6 & 1 & 5 & 4 & 6 & 3 & 7 & 9 & 2 & 8 & 1 & 7 \\
\hline & & & & & & & & & & & & & & & & & & & \\
\hline
\end{tabular}

\begin{tabular}{|l|l|l|l|l|l|l|l|l|l|l|l|l|l|l|l|l|l|l|l|}
\hline 9 & 4 & 6 & 8 & 5 & 9 & 7 & 1 & 8 & 5 & 2 & 9 & 4 & 8 & 6 & 3 & 7 & 9 & 8 & 6 \\
\hline & & & & & & & & & & & & & & & & & & & \\
\hline
\end{tabular}

\begin{tabular}{|l|l|l|l|l|l|l|l|l|l|l|l|l|l|l|l|l|l|l|l|}
\hline 2 & 7 & 3 & 6 & 5 & 1 & 9 & 8 & 4 & 5 & 7 & 3 & 1 & 4 & 8 & 7 & 9 & 1 & 4 & 5 \\
\hline & & & & & & & & & & & & & & & & & & & \\
\hline
\end{tabular}

\begin{tabular}{|l|l|l|l|l|l|l|l|l|l|l|l|l|l|l|l|l|l|l|l|}
\hline 7 & 1 & 8 & 2 & 9 & 3 & 6 & 7 & 2 & 8 & 5 & 2 & 3 & 1 & 4 & 8 & 4 & 2 & 7 & 6 \\
\hline & & & & & & & & & & & & & & & & & & & \\
\hline
\end{tabular}


Anexo XII

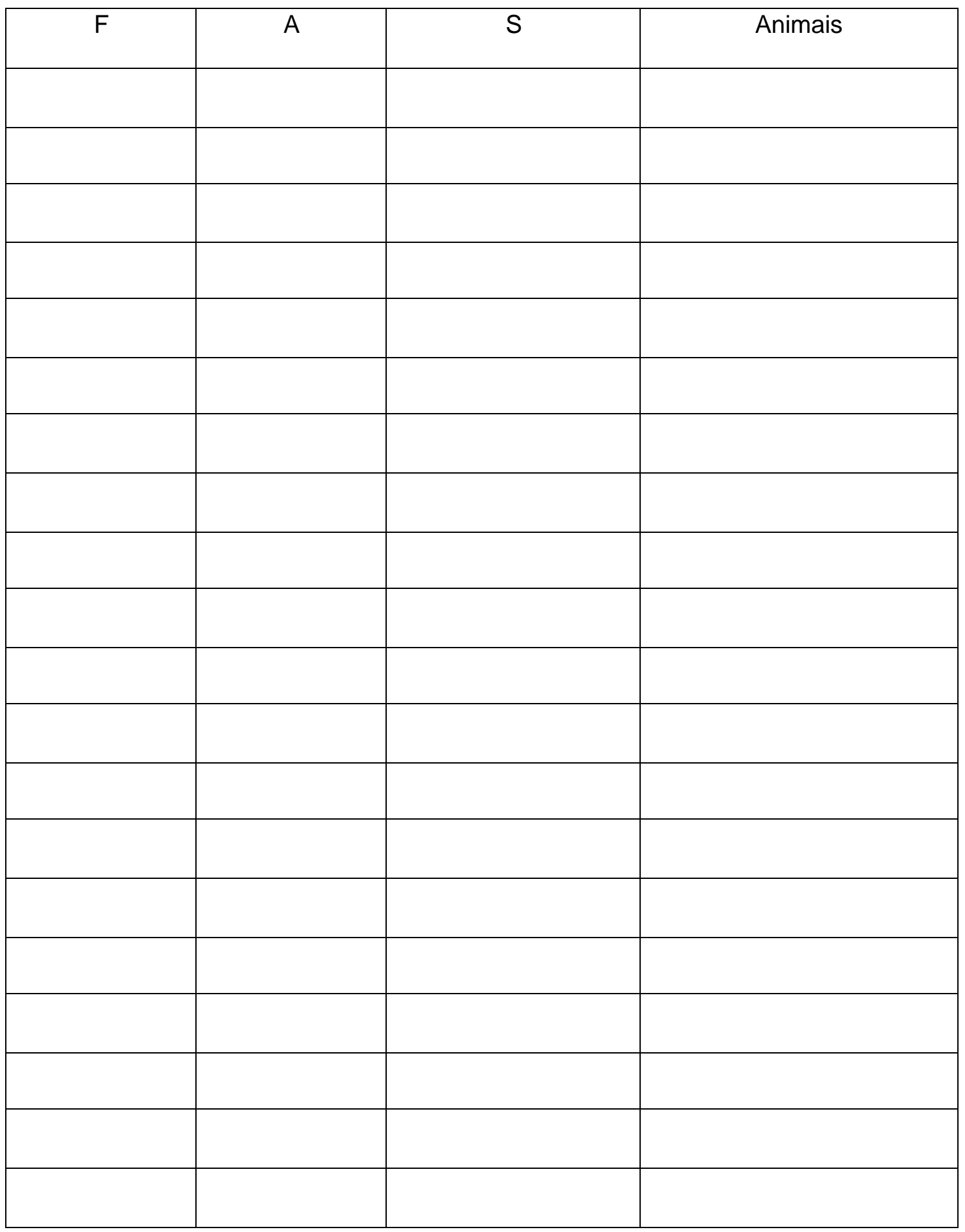


Anexo XIII

TESTE DE TRILHAS

Parte A

Exemplo

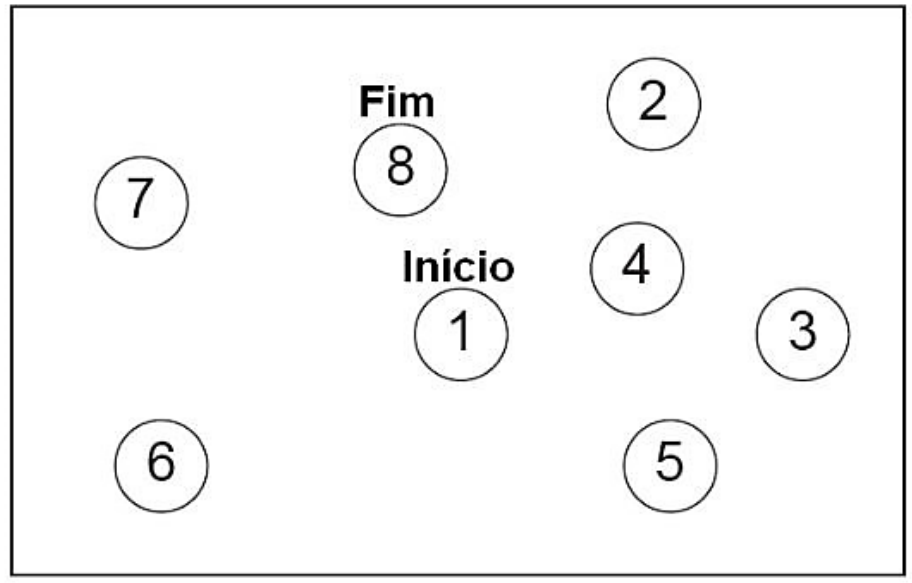


(15)

(17)

(21)

(20)

(19)

(16)

(18)

(5)

(4) (22)

(13)

(6)

(7)

Iníclo

(14)

(1) 24

(8) 10

(3)

(9)

(12)

(11) 25

(23) 
TESTE DE TRILHAS

Parte B

Exemplo

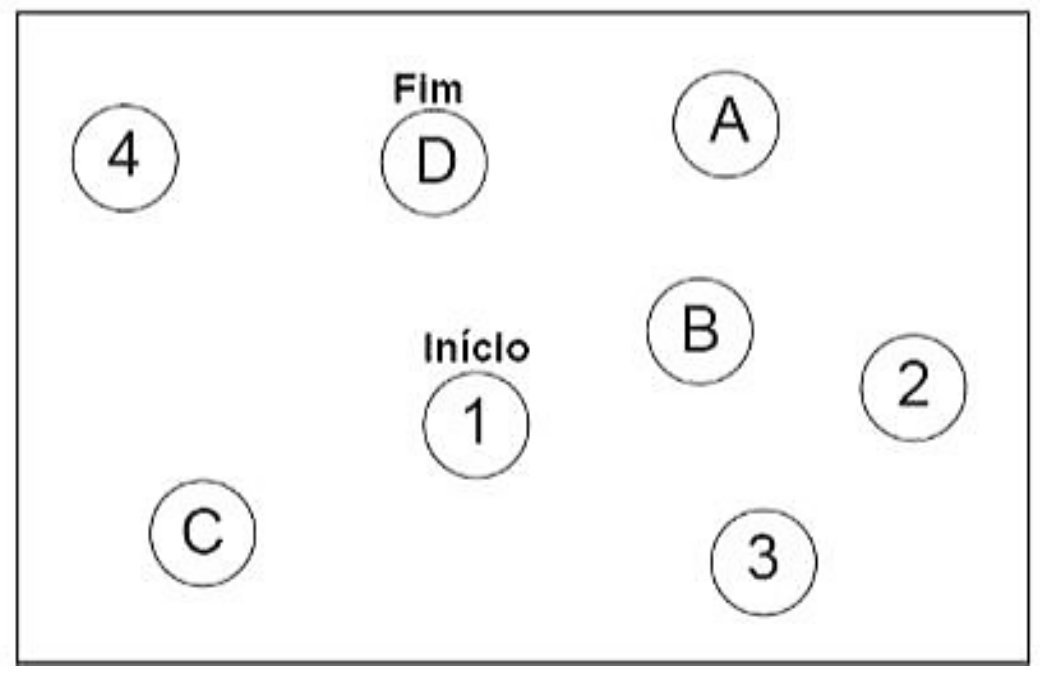


Fim

(13)

(8) (9)

(B) (I) (D)

(10)

(3)

(7) 1

(H)

(5)

(C)

(12)

(G)

(A) (J)

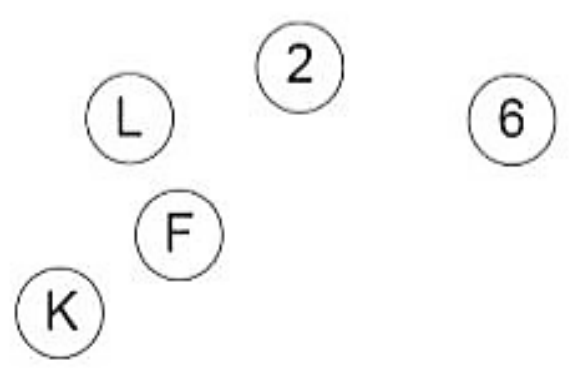

(E) 
Anexo XIV

Grooved Pegboard (iniciar com a mão dominante)

Dominância: ( ) Direita ( ) Esquerda

\begin{tabular}{|l|l|l|l|l|l|l|}
\hline $\begin{array}{l}\text { Mão } \\
\text { Dominante }\end{array}$ & $\begin{array}{l}\text { Res. } \\
\text { Pac. }\end{array}$ & Média & D.P. & Z: & Perc: & C: \\
\hline Tempo: & & & & & & \\
\hline $\begin{array}{l}\text { Pinos } \\
\text { derrubados }\end{array}$ & & & & & & \\
\hline
\end{tabular}

\begin{tabular}{|l|l|l|l|l|l|l|}
\hline $\begin{array}{l}\text { Mão Não } \\
\text { Dominante }\end{array}$ & $\begin{array}{l}\text { Res. } \\
\text { Pac. }\end{array}$ & Média & D.P. & Z: & Perc: & C: \\
\hline Tempo: & & & & & & \\
\hline $\begin{array}{l}\text { Pinos } \\
\text { derrubados }\end{array}$ & & & & & & \\
\hline
\end{tabular}


Anexo XV

TERMO DE CONSENTIMENTO LIVRE E ESCLARECIDO

Dados de identificação do sujeito da pesquisa

Nome:

Documento de Identidade $\mathrm{N}^{\mathrm{O}}$ :

Data de nascimento: 1 lation Idade: Sexo: $M() F(~)$

Endereço $\mathrm{N}^{\mathrm{O}}$ complemento. Bairro:

Cidade: CEP: Telefone: Celular:

Avaliação do risco da pesquisa: Mínimo

\section{DADOS SOBRE A PESQUISA:}

Título do protocolo de pesquisa: Prevalência de Alterações Neurocognitivas Associadas ao HIV em uma Coorte Aderente ao Antirretroviral de em um Hospital Geral na Cidade de São Paulo.

Pesquisador: Mayra Christina Campos Lima

Cargolfunção: Psicóloga

Inscrição no Conselho Regional de Psicologia: 06/98053

Orientador: Jorge Simão do Rosário Casseb

Cargo/função: Professor Doutor

Inscrição no Conselho Regional de Medicina: 67217

Unidade do HCFMUSP: Dermatologia - ADEE 3002

Colaborador: Maria Rita Polo Gascón

Cargo/função: Psicóloga

Inscrição no Conselho Regional de Psicologia: 06/85260

Unidade do HCFMUSP: Divisão de Psicologia do Instituto Central

Avaliação do risco da Pesquisa:

Risco mínimo (x) Risco médio ( )

Risco baixo ( ) Risco maior ( )

Duração da Pesquisa: 1 ano

Assinatura do paciente

Data $1 \quad 1$

Assinatura do pesquisador responsável

Data 1 I

HOSPITAL DAS CLÍNICAS DA FACULDADE DE MEDICINA DA UNIVERSIDADE DE SÃO PAULO-HCFMUSP 
Você está sendo convidado a participar de uma pesquisa intitulada: "Prevalência de Alterações Neurocognitivas Associadas ao HIV em uma Coorte Aderente ao Antirretroviral em um Hospital Geral na Cidade de São Paulo". Sua participação é muito importante para que possamos investigar se há alterações em sua capacidade de memorização, de realizar movimentos com as mãos, de resolver problemas, em seu estado de humor (triste ou ansioso) e de na capacidade de existir alguém em que você possa confiar, que se preocupa com você e/ou que goste de você, possa prejudicar no uso correto dos medicamentos para o HIV (antirretrovirais). Caso sejam identificados alguns destes aspectos, você terá acesso a todo o apoio necessário por parte da equipe multidisciplinar (médico, psicóloga, enfermeira e nutricionista) se assim o desejar.

Sua participação é completamente voluntária e você é livre para recusar caso não se sinta à vontade para participar.

Caso você opte por participar, a pesquisa consistirá na realização de uma entrevista e aplicação de 7 instrumentos:

1) A entrevista contém questões sobre dados demográficos e clínicos como sexo, idade, orientação sexual, data do diagnóstico da infecção pelo HIV, mecanismo de transmissão da infecção, uso de álcool e outras substâncias psicoativas; dados clínicos: uso atual e histórico de antirretrovirais; dados laboratoriais: contagem de linfócitos CD4+ e quantificação da carga viral do HIV-1. Serão considerados os resultados laboratoriais mais próximos à avaliação clínica (até 3 meses antes);

2) Escala de Depressão e Ansiedade e Hospitalar (HADS);

3) Questionário para avaliar as atividades de vida diária - Escala de Lawton e Brody;

4) Questionário de rastreio de alterações neurocognitivas em pacientes infectados por HIV-1 - International HIV Dementia Scale (IHDS);

5) Avaliação Neuropsicológica estruturada formada por: Subtestes da escala WAIS-III (Códigos e Dígitos de ordem direta e indireta), The Rey Auditory-Verbal Learning Test, Trail Making Test $A$ and B, Fluência Verbal Categórica: Animais + FAS e Grooved Pegboard.

6) Escala de Suporte Social para Pessoas Vivendo com HIVIAids;

7) CEAT-VIH - Questionário de avaliação da adesão ao tratamento antirretroviral A aplicação dos questionários acontecerá em uma sala localizada no Hospital das Clínicas com duração de, aproximadamente, 60 minutos. A pesquisa apresenta risco mínimo aos participantes, ou seja, você pode ficar cansado durante a aplicação dos testes. Caso isso ocorra, por favor, avise o avaliador.

O dia e horário para a realização das atividades acima será combinado anteriormente com você e, caso queira desistir da pesquisa a qualquer momento, você não será prejudicado nos atendimentos em qualquer serviço deste hospital.

Caso haja alguma dúvida, durante qualquer etapa do estudo, sinta-se à vontade para falar conosco entrando em contato com o pesquisador responsável, Dr. Jorge Simão do Rosário Casseb, pelo número de telefone do LIM/56 - Laboratório de Investigação em Dermatologia e Imunodeficiências: (11) 3061-7193. Se você tiver alguma consideração ou dúvida sobre a ética da pesquisa, entre em contato com o Comitê de Ética em Pesquisa (CEP) - Rua Ovídio Pires de Campos, 225 - 5º andar - tel: 2661-6442 ramais 16, 17, 18 - e-mail: cappesq@hcnet.usp.br.

É garantida a liberdade da retirada de consentimento a qualquer momento e deixar de participar do estudo, sem qualquer prejuízo à continuidade de seu tratamento na Instituição.

As informações obtidas serão analisadas em conjunto com outros pacientes, não sendo divulgado a identificação de nenhum paciente;

Não há despesas pessoais para o participante em qualquer fase do estudo, incluindo exames e consultas. Também não há compensação financeira relacionada à sua participação. 


\section{HOSPITAL DAS CLÍNICAS DA FACULDADE DE MEDICINA DA UNIVERSIDADE DE SÃO PAULO-HCFMUSP}

$\mathrm{Eu}$, li este

Termo de consentimento e conversei com o os pesquisadores sobre a minha decisão em participar nesse estudo. Ficaram claros para mim quais são os propósitos do estudo, os procedimentos a serem realizados, seus desconfortos e riscos, as garantias de confidencialidade e de esclarecimentos permanentes. Ficou claro também que minha participação é isenta de despesas e que tenho garantia do acesso a tratamento hospitalar quando necessário. Concordo voluntariamente em participar deste estudo e poderei retirar o meu consentimento a qualquer momento, antes ou durante o mesmo, sem penalidades ou prejuízo ou perda de qualquer benefício que eu possa ter adquirido, ou no meu atendimento neste Serviço. Confirmo que recebi 1 (uma) cópia do presente termo de consentimento.

$\overline{\text { Assinatura do paciente Data / I }}$

Declaro que obtive de forma apropriada e voluntária o Consentimento Livre e

Esclarecido deste paciente ou representante legal para a participação neste estudo.

$\overline{\text { Assinatura do pesquisador responsável }}$ Data $\quad / \quad /$ 


\section{Referência Bibliográfica}

1. Centers for disease control and prevention. HIV Surveillance Report. [Online].; 2015. [cited 2017 January. Available from: http://www.cdc.gov/hiv/library/reports/hivsurveillance.html2016

2. UNAIDS. Global Aids Update. [Online].; 2016 [cited 2017 January. Available from: http://www.unaids.org/sites/default/files/media_asset/global-AIDS-update2016_en.pdf.

3. Nightingale S et al. Controversies in HIV-associated neurocognitive disorders. Lancet Neurol. 2014;13(11):1139-51.

4. Troncoso FT, Conterno LO. Prevalence of neurocognitive disorders and depression in a Brazilian HIV population. Rev Soc Bras Med Trop. 2015;48(4):390-8.

5. Chan P, Brew BJ. HIV associated neurocognitive disorders in the modern antiviral treatment era: prevalence, characteristics, biomarkers, and effects of treatment. Curr HIVIAIDS Rep. 2014;11(3):317-24.

6. Sheppard DP et al. Random Number Generation in HIV Disease: Associations with Neuropsychological Functions and Activities of Daily Living. Arch Clin Neuropsychol. 2017;32(1):53-62.

7. Ellis R J et al. Randomized Trial of Central Nervous System-Targeted Antiretrovirals for HIV-Associated Neurocognitive Disorder. Clin Infect Dis. 2014;7:1015-22.

8. UNAIDS Brasil. Prevention Gap Report. [Online].; 2016 [cited 2017 January. Available from: http://www.unaids.org/en/resources/documents/2016/prevention-gap.

9. Heikinheimo T et al. Three-decade neurological and neurocognitive follow-up of HIV-1 infected patients on best-available antiretroviral therapy in Finland. BMJ Open. 2015;5(11):e007986.

10. Fuentes D et al. Neuropsicologia: Teoria e Prática. $2^{\mathrm{a}}$ ed. Porto Alegre: Artmed; 2013. 432p.

11. Brew BJ, Chan P. Update on HIV dementia and HIV-associated neurocognitive disorders. Curr Neurol Neurosci Rep. 2014;14(8):468.

12. Haziot M E J et al. Neuroimaging of HIV-associated neurocognitive disorders. Dementia \& Neuropsychologia. 2015;9:380-4.

13. Tsegaw M, Andargie G, Alem G, Tareke M. Screening HIV-associated neurocognitive disorders (HAND) among HIV positive patients attending antiretroviral therapy in South Wollo, Ethiopia. J Psychiatr Res. 2017;85:37-41.

14. Ian E et al. The burden of HIV-associated neurocognitive disorder (HAND) in the Asia-Pacific region and recommendations for screening. Asian J Psychiatr. 2016;22:182-9. 
15. Thaler NS et al. Increased neurocognitive intra-individual variability is associated with declines in medication adherence in HIV-infected adults. Neuropsychology. 2015;29(6):919-25.

16. Thaler NS et al. Interactive effects of neurocognitive impairment and substance use on antiretroviral non-adherence in HIV disease. Arch Clin Neuropsychol. 2015;30(2):114-21.

17. McArthur JC, Steiner J, Sacktor N, Nath A. Human immunodeficiency virusassociated neurocognitive disorders: Mind the gap. Ann Neurol. 2010;67(6):699-714.

18. Tavazzi E et al. Brain inflammation is a common feature of HIV-infected patients without HIV encephalitis or productive brain infection. Current HIV Research. 2014;12(2):97-110.

19. Letendre S. Central nervous system complications in HIV disease: HIVassociated neurocognitive disorder. Top Antivir Med. 2011;19(4):137-42.

20. Departamento de vigilância, prevenção e controle das IST, do HIVIAids e das Hepatites Virais. Avaliação Neuropsicológica. [Online].; 2014. [cited 2017 January. Available from: http://www.aids.gov.br/pcdt/4.

21. Antinori A et al. Updated research nosology for HIV-associated neurocognitive disorders. Neurology. 2007;69(18):1789-99.

22. Sacktor $\mathrm{N}$ et al. Prevalence of HIV-associated neurocognitive disorders in the Multicenter AIDS Cohort Study. Neurology. 2016;86(4):334-40.

23. Brouillette MJ et al. Identifying Neurocognitive Decline at 36 Months among HIV-Positive Participants in the CHARTER Cohort Using Group-Based Trajectory Analysis. PLoS One. 2016;11(5):e0155766.

24. Simioni S et al. Cognitive dysfunction in HIV patients despite long-standing suppression of viremia. AIDS. 2010;24(9):1243-50.

25. Grant I et al. Asymptomatic HIV-associated neurocognitive impairment increases risk for symptomatic decline. Neurology. 2014;82(23):2055-62.

26. Wright EJ et al. NeuroAIDS in the Asia Pacific Region. J Neurovirol. 2008;14(6):465-73.

27. Coatsworth AM et al. HIV-Related Sexual Risk among African American Men Preceding Incarceration: Associations with Support from Significant Others, Family, and Friends. J Urban Health. 2017.

28. Vassallo $\mathrm{M}$ et al. Virologically suppressed patients with asymptomatic and symptomatic HIV-associated neurocognitive disorders do not display the same pattern of immune activation. HIV Med. 2015;16(7):431-40.

29. Cysique LA et al. The role of depression chronicity and recurrence on neurocognitive dysfunctions in HIV-infected adults. J Neurovirol. 2016;22(1):56-65. 
30. Pinheiro CAT. Alterações neurocognitivas por comprometimento subcortical em pacientes com HIV / AIDS em uma região do sul do Brasil [Dissertação] Universidade Catolica de Pelotas. [Online].; 2016 [cited 2016 December. Available from: http://tede.ucpel.edu.br:8080/tede/handle/tede/512

31. Rocha BA. Rastreio de transtornos neurocognitivos, depressão e ansiedade em pessoas com hiv/aids. s.n. ed. S.I.2011.

32. Fernandes Filho SM, de Melo HR. Frequency and risk factors for HIVassociated neurocognitive disorder and depression in older individuals with HIV in northeastern Brazil. Int Psychogeriatr. 2012;24(10):1648-55.

33. Kalil RS, Alvarenga RMP, Almeida AJD, Morais-de-Sá CA. Estudo dos transtornos cognitivos decorrentes da infecção pelo HIV-1. Estudos de Psicologia (Campinas). 2009;26:465-73.

34. Oliveira JF et al. Neurological disease in HIV-infected patients in the era of highly active antiretroviral treatment: a Brazilian experience. Rev Soc Bras Med Trop. 2006;39(2):146-51.

35. Troncoso FT. Estudo da Prevalência de Alterações Neurocognitivas e Transtorno Depressivo em Popuplação Soropositiva para o HIV em Marília [Dissertação]. Faculdade de Medicina de Marília. [Online].; 2013 [cited 2016 November. Available from:

http://www.famema.br/ensino/mestrado_acade/mestrado_dissertacoes.php

36. Passos SM, Souza LD, Spessato BC. High prevalence of suicide risk in people living with HIV: who is at higher risk? AIDS Care. 2014;26(11):1379-82.

37. Brasil, Ministério da Saúde. Manual Técnico para o Diagnóstico da Infecção pelo HIV. [Online].; 2016. [cited 2016 November. Available from: http://www.aids.gov.br/sites/default/files/anexos/publicacao/2013/55594/manual tecnic o hiv 2016 final 2507 pdf 54115.pdf.

38. Côté $\mathrm{J}$ et al. Predictors and Evolution of Antiretroviral Therapy Adherence Among Perinatally HIV-Infected Adolescents in Brazil. J Adolesc Health. 2016;59(3):305-10.

39. Seidl EMF, Tróccoli BT. Desenvolvimento de escala para avaliação do suporte social em HIV/aids. Psicologia: Teoria e Pesquisa. 2006;22:317-26.

40. Wang $\mathrm{H}$, Zhang C, Ruan Y, Li X, Fennie K, Williams AB. Depressive symptoms and social support among people living with HIV in Hunan, China. J Assoc Nurses AIDS Care. 2014;25(6):568-76.

41. Kamat $\mathrm{R}$ et al. Incident major depressive episodes increase the severity and risk of apathy in HIV infection. J Affect Disord. 2015;175:475-80.

42. Blazer DG. Depression in late life: review and commentary. J Gerontol A Biol Sci Med Sci. 2003;58(3):249-65.

43. Rozenthal M, Laks J, Engelhardt E. Aspectos neuropsicológicos da depressão. Revista de Psiquiatria do Rio Grande do Sul. 2004;26:204-12. 
44. Zakzanis KK, Leach L, Kaplan E. Neuropsychological Differential Diagnosis. USA: Swets \& Zeitlinger; 1999.

45. Alexopoulos GS et al. Clinical presentation of the depression executive dysfunction syndrome of late life. American Journal of Geriatric Psychiatry. 2002;10(1):98-106.

46. Alexopoulos GS. Depression in the elderly. Lancet. 2005;365(9475):1961-70.

47. Warren-Jeanpiere $L$ et al. Life begins at 60 : Identifying the social support needs of African American women aging with HIV. J Health Care Poor Underserved. 2017;28(1):389-405.

48. Pedrosa SC et al. Social support for people living witj acquired immunodeficiency syndrome. Texto \& Contexto - Enfermagem. 2016;25.

49. De Marchi MC. Suporte Social e Adesão ao Tratamento Antirretroviral de Adultos que Vivem com HIVIAids. [Dissertação]. Universidade Federal de Santa Maria. [Online].;2014 [cited 2016 December. Available from: http://cascavel.ufsm.br/tede//tde busca/arquivo.php?codArquivo=6912

50. Santos WM. Terapia Antirretroviral de Adultos Infectados pelo HIV: do Suporte Social à Terapia de Auto eficácia. [Dissertação]. Universidade Federal de Santa Maria. [Online].; 2014 [cited 2016 December. Available from: http://cascavel.ufsm.br/tede//tde busca/arquivo.php?codArquivo=6704

51. Passos SM, Souza LD. An evaluation of quality of life and its determinants among people living with HIVIAIDS from Southern Brazil. Cad Saude Publica. 2015;31(4):800-14.

52. Portella M J, Marcos-Bars T. Implicación del lóbulo frontal en la depresión mayor senil. Revista de Neurologia. Rev Neurol 2002;35(9):891-4.

54. Sacktor NC et al. The International HIV Dementia Scale: a new rapid screening test for HIV dementia. AIDS. 2005;19(13):1367-74.

55. Lawton MP, Brody EM. Assessment of older people: self-maintaining and instrumental activities of daily living. Gerontologist. 1969;9(3):179-86.

56. Santos R L, Junior JSV. Confiabilidade da versão Brasileira da Escala de Atividades Instrumentais da Vida Diária. Brazilian Journal in Health Promotion. 2008;21(4):290-6.

57. Zigmond AS, Snaith RP. The hospital anxiety and depression scale. Acta Psychiatr Scand. 1983;67(6):361-70.

58. Botega NJ et al. Transtornos do humor em enfermaria de clínica médica e validação de escala de medida (HAD) de ansiedade e depressão. Revista de Saúde Pública. 1995;29:359-63.

59. WHO ASSIST Working Group. The Alcohol, Smoking and Substance Involvement Screening Test (ASSIST): development, reliability and feasibility. Addiction. 2002;97(9):1183-94. 
60. Henrique IFS et al. Validação da versão brasileira do teste de triagem do envolvimento com álcool, cigarro e outras substâncias (ASSIST). Revista da Associação Médica Brasileira. 2004;50:199-206.

61. Renwick R, Halpen T, Rudman D, Friedland J. Description and validation of a measure of received support specific to HIV. Psychol Rep. 1999;84(2):663-73.

62. Remor E. Valoración de la adhesión al tratamiento antirretroviral en pacientes $\mathrm{VIH}+$. Psicothema. 2002;14(2):262-67.

63. Remor E, Milner-Moskovics J, Preussler G. Adaptação brasileira do "Cuestionario para la Evaluación de la Adhesión al Tratamiento Antiretroviral". Revista de Saúde Pública. 2007;41:685-94.

64. Wechsler D. WAIS III- Escala de inteligência para adultos: manual: Casa do Psicólogo; 2004. 412 p.

65. Malloy-Diniz LF et al. The Rey Auditory-Verbal Learning Test: applicability for the Brazilian elderly population. Rev Bras Psiquiatr. 2007;29(4):324-9.

66. Strauss E, Sherman E, Spreen O. A compendium of neuropsychological tests: Administration, norms, and commentary. 3 ed. New York: Oxford University Press; 2006.

67. Tombaugh TN. Trail Making Test A and B: normative data stratified by age and education. Arch Clin Neuropsychol. 2004;19(2):203-14.

68. Ruff RM, Parker SB. Gender- and age-specific changes in motor speed and eye-hand coordination in adults: normative values for the Finger Tapping and Grooved Pegboard Tests. Percept Mot Skills. 1993;76(3 Pt 2):1219-30.

69. Dancey CP, Reidy J. Estatística sem Matemática para Psicologia: usando SPSS para Windows. 3 ed. Porto Alegre: Artmed; 2006. 